\title{
Panorama industrial da região de Irati-União da Vitória: 1995-2003
}

Maria Aparecida de Oliveira ${ }^{1}$

Resumo:Este artigo objetiva descrever o panorama industrial da Região de Irati-União da Vitória no período 1999-2003. Para isso, desenvolveu-se uma metodologia para análise de desenvolvimento regional, baseada em variáveis-chave e na matriz regional-econômica da região. Os resultados mostram que a estrutura produtiva da região tem sua maior representatividade no grupo madereiro e minerais não-metálicos. Comparativamente a outras regiões, as atividades agroindustriais são ainda frágeis na região, tendo na erva-mate e no fumo as maiores produções. Diante dos investimentos anunciados e da mobilização dos agentes locais, há forte tendência de permanência dessa matriz produtiva na região.

Palavras-chave: Região de Irati-União da Vitória; sudeste paranaense; economia regional.

\section{The industrial landscape of Irati-União da Vitória: 1995-2003}

\begin{abstract}
The present article aims at describing the industrial panorama of Irati-União da Vitória Region from 1999 to 2003. To that end we developed a methodology addressed to regional development analysis which is based on key-variables and on that region economic-regional matrix. The results show that the region productive structure is mostly represented by the wood and nonmetallic mineral groups. Such region agro-industrial activities are still fragile if compared to the other regions. Yerba maté and tobacco are its main products. We inferred that there is a strong trend to keep that production matrix unchanged due to the investments already planned and the mobilization of local agents.
\end{abstract}

Key words:Irati-União da Vitória Region; Paraná southeast; regional economics.

JEL: Ro; R3

1 Economista e pesquisadora do Instituto Paranaense de Desenvolvimento Econômico e Social (Ipardes). Mestre em Teoria Econômica pela Universidade Estadual de Maringá. E-mail: cida_oliveira@terra.com.br 


\section{Introdução}

Uma região não cresce abruptamente e nem tem morte súbita; é o constante movimento ou a acomodação estática que determina como as regiões evoluem. Entretanto, são diversas as portas de entrada e os olhares na constituição desse processo. A redescoberta do local (região) como território organizado, seu fortalecimento e a busca compartilhada de soluções vêm exigindo um novo comportamento por parte dos atores locais e das instituições intervenientes.

Nesse sentido, o presente artigo pretende, além da análise da região de Irati-União da Vitória, fomentar a discussão e a conceituação das questões relativas às metodologias de análise regional. $\mathrm{O}$ modelo proposto é baseado na utilização de variáveis-chave tendo como referência a matriz regional-econômica desenvolvida por Oliveira (2005), que é constituída por segmentos industriais representativos da região.

O artigo está organizado em quatro tópicos: a discussão sobre a metodologia desenvolvida para a análise regional; o seguinte descreve e analisa a economia regional utilizando-se da metodologia apresentada; o terceiro trata dos fatores sistêmicos regionais, e o último traz considerações finais.

\section{Metodologia de análise regional}

A metodologia construída, cujas informações essenciais encontram-se no Quadro 1, consiste na utilização do instrumental da matriz regionaleconômica definida por Oliveira (2005), que é composta de 1.280 pares de segmentos-região (16 regiões X 80 segmentos representativos) aplicados na base de dados das variáveis-chave. A análise tem como foco as células produtivas do segmento-região em torno das quais se deduz ocorrer todo e qualquer processo de atração, desenvolvimento, reestruturação e consolidação da estrutura industrial de uma região.

Tomou-se um período crítico de sete anos - tempo consideravelmente razoável para se perceber alterações significativas do cenário industrial de uma região -, analisando cinco anos das variáveis-estrutura e váriáveis-complemento e dois anos das variáveis-prospecção.

A análise das variáveis-estrutura conjuga aspectos ou elementos que são básicos para a caracterização da estrutura industrial, tais como Valor Adicionado Fiscal (VAF) da Secretaria da Fazenda do Estado do Paraná-Sefa (utilizada como proxy da renda industrial), número de empregados, número de estabelecimentos. Outras variáveis-estrutura importantes diz respeito à composição do perfil laboral com base em da- 
dos da Relação Anual de Informações Sociais do Ministério do Trabalho (RAIS-MTE), que traz informações sobre escolaridade, faixa salarial, ocupação, faixa etária e gênero. Por meio das variáveis-estrutura pretende-se realizar uma investigação no "varejo" das particularidades produtivas das indústrias nas regiões, procurando captar suas bases de sustentação e alavancagem.

\section{QUADRO 1. METODOLOGIA PARA ANÁLISE REGIONAL}

\begin{tabular}{|c|c|c|c|}
\hline $\begin{array}{l}\text { TIPOLOGIA } \\
\text { VARIÁVEIS- } \\
\text { CHAVE }\end{array}$ & VARIÁVEIS & ESTRATIFICAÇÕES & $\begin{array}{l}\text { FONTE DE } \\
\text { INFORMAÇÕES }\end{array}$ \\
\hline Período analisado & $\begin{array}{l}\text { Período crítico } \\
7 \text { anos }\end{array}$ & $\begin{array}{l}5 \text { anos para variáveis-chave e variáveis- } \\
\text { complemento } \\
2 \text { anos para variáveis prospectiva }\end{array}$ & \\
\hline \multirow{8}{*}{$\begin{array}{l}\text { Variáveis- } \\
\text { estrutura }\end{array}$} & Renda industrial & Valor Adicionado Fiscal & SEFA \\
\hline & Emprego Industrial & Número de postos trabalho ocupado & RAIS-MTE \\
\hline & $\begin{array}{l}\text { Estabelecimentos } \\
\text { industriais }\end{array}$ & Número de estabelecimentos & $\begin{array}{l}\text { SEFA ou RAIS-MTE (o } \\
\text { que apresentar maior } \\
\text { magnitude) }\end{array}$ \\
\hline & Grau de instrução & $\begin{array}{l}\text {-básico: de o a } 7 \text { anos de estudos (analfabetos, } 4 \cdot^{\mathrm{a}} \\
\text { série incompleta, } 4 \cdot^{\mathrm{a}} \text { série completa e } 8 \cdot^{\mathrm{a}} \text { série } \\
\text { incompleta); } \\
\text {-fundamental: de } 8 \text { a } 10 \text { anos de estudos ( } 8 \cdot^{\mathrm{a}} \text { série } \\
\text { completa e } 2 .^{\circ} \text { grau incompleto); } \\
\text {-médio: de } 11 \text { a } 13 \text { anos de estudos ( } 2 .^{\circ} \text { grau } \\
\text { completo ou superior incompleto); } \\
\text {-superior: } 15 \text { anos de estudos ou mais (superior } \\
\text { completo) }\end{array}$ & RAIS-MTE \\
\hline & $\begin{array}{l}\text { Faixa Salarial } \\
\text { Em Salários } \\
\text { Mínimos (SMs) }\end{array}$ & $\begin{array}{l}\text {-até } 2,00 \mathrm{SMs} \\
\text {-entre 2,01 SMs e 4,00 SMs; } \\
\text {-entre 4,01 SMs e 7,00 SMs; } \\
\text {-entre 7,01 SMs e 15,00 SMs; } \\
\text {-maior que 15,01 SMs }\end{array}$ & RAIS-MTE \\
\hline & Faixa etária & $\begin{array}{l}\text {-Até } 24 \text { anos de idade; } \\
\text {-entre } 25 \text { e } 39 \text { anos de idade; } \\
\text {-40 anos de idade ou mais. }\end{array}$ & RAIS-MTE \\
\hline & Gênero & $\begin{array}{l}\text {-Masculino } \\
\text {-Feminino }\end{array}$ & RAIS-MTE \\
\hline & Ocupação & Classificação Brasileira das Ocupações (CBO) & RAIS-MTE \\
\hline \multirow{4}{*}{$\begin{array}{l}\text { Variáveis- } \\
\text { complemento }\end{array}$} & $\begin{array}{l}\text { Produção } \\
\text { silviagropecuária }\end{array}$ & Área plantada (hectares) & SEAB/DERAL \\
\hline & $\begin{array}{l}\text { Produção } \\
\text { silviagropecuária }\end{array}$ & Produção (toneladas) & SEAB/DERAL \\
\hline & $\begin{array}{l}\text { Produção } \\
\text { silviagropecuária }\end{array}$ & Animais-Abate (cabeças) & SEAB/DERAL \\
\hline & Produção mineral & Produção mineral (toneladas, $\mathrm{m}^{2}, \mathrm{~m}^{3}$ ) & MINEROPAR \\
\hline \multirow{7}{*}{$\begin{array}{l}\text { Variáveis- } \\
\text { prospecção }\end{array}$} & Ativos Tecnológicos & $\begin{array}{l}\text { Instituições ensino superior regional } \\
\text { Cursos com ênfase industrial (superior, técnico e } \\
\text { formação profissional) }\end{array}$ & $\begin{array}{l}\text { Canais próprio de } \\
\text { divulgação e imprensa }\end{array}$ \\
\hline & Ativos Institucionais & $\begin{array}{l}\text { Instituições de extensionismo e apoio empresarial } \\
\text { Agências locais, estaduais e federais e agências de } \\
\text { desenvolvimento } \\
\text { Instituições de apoio tecnológico e financeiro }\end{array}$ & $\begin{array}{l}\text { Canais próprio de } \\
\text { divulgação e imprensa }\end{array}$ \\
\hline & Ativos Institucionais & Prefeituras, Governo do Estado, Governo Federal & $\begin{array}{l}\text { Canais próprio de } \\
\text { divulgação e imprensa }\end{array}$ \\
\hline & $\begin{array}{l}\text { Îndice de } \\
\text { Empreendedorismo }\end{array}$ & $\begin{array}{l}\text { Abertura de novas empresas Junta Comercial e } \\
\text { prefeituras }\end{array}$ & \\
\hline & Investimentos & Investimentos anunciados & $\begin{array}{l}\text { Jornais, revistas e sites } \\
\text { institucionais }\end{array}$ \\
\hline & Capital Social & $\begin{array}{l}\text { Instituições representativas (sindicatos, } \\
\text { associações) }\end{array}$ & Internet e imprensa \\
\hline & Capital Social & $\begin{array}{l}\text { Movimentos, pactos e eventos } \\
\text { Fóruns, conselhos e câmaras setoriais }\end{array}$ & Órgãos de divulgação \\
\hline
\end{tabular}


As variáveis-complemento (que expressam uma provável relação dinâmica entre a agricultura, a agroindústria, a extração e a transformação dos bens minerais) englobam as atividades a montante dos segmentos agroindustriais, com dados da produção silvi-agropecuária municipal anual fornecidos pela Secretaria de Estado da Agricultura e do Abastecimento do Paraná (Seab/Debral), e extração mineral, com dados da produção mineral municipal anual disponibilizados pela Minerais do Paraná (Mineropar).

Já as variáveis-prospecção (que aqui devem ser entendidas como sinalizadoras de tendência) dizem respeito às informações sobre decisões de investimentos das empresas, anunciados em jornais de circulação nacional, estadual e regional, nos dois anos subseqüentes ao período disponibilizado para as variáveis-estrutura. Também foram consideradas como variáveis-prospecção as atividades mobilizadoras advindas das instituições locais e do ambiente regional de negócios, cursos de educação formal e formação da mão-de-obra, bem como ações públicas de fomento às atividades industriais da região. Outro elemento importante (ainda não utilizado para análise da região de Irati-União da Vitória) é o aqui denominado índice de empreendedorismo advindo de taxa média anual de abertura de novas empresas industriais na região com dados fornecidos pela Junta Comercial.

Após a aplicação da metodologia pretende-se identificar as atividades estruturantes, as atividades potenciais, o capital social, os ativos tecnológicos e institucionais, os dilemas, e os gargalos e as oportunidades existentes na região.

É pertinente observar que a metodologia aqui apresentada para análise regional não objetiva ser definitiva para fins de elaboração de projetos e ações governamentais e não-governamentais, mas oferece fortes pistas e as trilhas a serem percorridas por investigações mais detalhadas ou estudo de caso com pesquisa de campo. Os elementos gerados pela aplicação da metodologia pretendem contribuir para elucidar aspectos fundamentais para a realização de mapeamento mínimo da economia regional.

\section{Análise da economia regional}

O Estado do Paraná ocupa o quarto lugar na representação econômica entre as unidades federativas do Brasil. Segundo dados de 2002 do Instituto Paranaense de Desenvolvimento Econômico e Social (Ipardes), o Estado do Paraná contabilizou um PIB de R\$ 81,4 bilhões, correspondendo a $6 \%$ do PIB nacional, e obteve um PIB per capita de R $\$$ 8.241,00. De acordo com o Censo de 2000, do IBGE, o Paraná contava com 9,5 milhões de habitantes, dos quais 7,8 milhões encontravam-se 
na área urbana $(81,4 \%)$ e 1,7 milhões, na área rural, distribuídos nos seus 399 municípios. A área total do Estado é de 199.554 quilômetros quadrados. Em 2003, a indústria extrativa e de transformação paranaense comportava 32.884 estabelecimentos abrigando um contingente de 432.040 trabalhadores (RAIS-MTE 2003).

A Região de Irati-União da Vitória é uma das regiões que formam o "Paraná Tradicional"; os municípios que a compõem são em sua maioria de colonização antiga, criados no final do século XIX e início do século XX. Os municípios mais antigos - Imbituva (1885), São João do Triunfo (1890) e Ipiranga (1894) - foram colonizados pelos tropeiros que vinham do Rio Grande do Sul, em direção a Minas Gerais e São Paulo, levando mulas, couro, objetos de couro, charque e outros mantimentos. Com o crescimento das cidades, houve necessidade de atrair imigrantes estrangeiros para a produção de alimentos, e então ali se instalaram imigrantes poloneses, ucranianos, alemães e russos (Bandeira 1995:234). A Região é constituída por 21 municípios (ver Tabela 1), que ocupam uma área total de $17.009 \mathrm{~km}^{2}$, e está assentada nas bacias hidrográficas dos rios Iguaçu e Tibagi. Em 2000, a Região possuía 377.274 habitantes, dos quais 53,6\% na área urbana. A maioria dos municípios conta com extensas áreas; 19 deles possuem áreas superiores as $300 \mathrm{~km}^{2}$. Dois municípios foram criados em 1996: Fernandes Pinheiro (desmembrado de Teixeira Soares) e Guamiranga (desmembrado de Imbituva). Cabe observar que a maioria dos municípios tem apresentando estagnação ou pouco crescimento vegetativo da população, como é o caso de Antônio Olinto e Paulo Frontin, que têm contabilizado perda no contigente populacional.

A Região Irati-União da Vitória contava, em 2003, com 1.669 estabelecimentos industriais, distribuídos em 62 segmentos representativos (resultante da aplicação da matriz regional-econômica) que ofertaram 16.112 postos de trabalho em 1999 e 17.525 em 2003, com crescimento de 8,8\%, correspondendo a 4,8\% em 1999 e 4,1\% em 2003 na participação do total de empregos industriais do Estado. Na composição do VAF Estadual, a participação da Região apresentou queda, passando de 2,2\% em 1999 para 1,9\% em 2003 (Sefa 2003).

Em 2003, os três municípios que mais contribuíram para a formação do VAF da indústria da Região foram: Mateus do Sul (23,8\%), União da Vitória (22,8\%) e Irati (15,7\%), perfazendo um total 62,3\%. Na participação municipal no total de empregos industriais da Região, em 2003, acumulando 55,6\% da mão-de-obra industrial ocupada, o ranking altera-se na segunda posição, sendo os três principais municípios: União da Vitória (23,6\%), Irati $(16,1 \%)$ e Imbituva (14,8\%), como apresentado na Tabela 1. 
TABELA 1. TOTAL DE ESTABELECIMENTOS, DE EMPREGADOS E PARTICIPAÇÃO NO VALOR ADICIONADO FISCAL DA INDÚSTRIA DOS MUNICÍPIOS DA REGIÃO IRATI-UNIÃO DA VITÓRIA - PARANÁ - 1999/2003

\begin{tabular}{|c|c|c|c|c|c|c|c|c|c|}
\hline \multirow[t]{3}{*}{ MUNICÍPIO } & \multirow{3}{*}{ População } & \multirow{2}{*}{\multicolumn{2}{|c|}{$\begin{array}{c}\text { TOTAL } \\
\text { DE } \\
\text { ESTABELECIMENTOS }\end{array}$}} & \multicolumn{4}{|c|}{ EMPREGADOS } & \multirow{2}{*}{\multicolumn{2}{|c|}{$\begin{array}{c}\text { PART. NO } \\
\text { VAF DA } \\
\text { REGIÃO (\%) }\end{array}$}} \\
\hline & & & & \multicolumn{2}{|c|}{1999} & \multicolumn{2}{|c|}{2003} & & \\
\hline & & 1999 & 2003 & Abs. & $\%$ & Abs. & $\%$ & 1999 & 2003 \\
\hline Antônio Olinto & 7.407 & 17 & 14 & 71 & 0,4 & 33 & 0,2 & 0,1 & 0,1 \\
\hline Bituruna & 15.733 & 161 & 145 & 1.040 & 6,5 & 1.284 & 7,3 & 5,5 & 5,3 \\
\hline Cruz Machado & 17.667 & 55 & 59 & 322 & 2,0 & 584 & 3,3 & 1,4 & 1,7 \\
\hline Fernandes Pinheiro & 6.368 & 22 & 22 & 244 & 1,5 & 229 & 1,3 & 3,1 & 0,8 \\
\hline General Carneiro & 13.899 & 106 & 90 & 1.059 & 6,6 & 1.027 & 5,9 & 3,9 & 3,0 \\
\hline Guamiranga & 7.134 & 13 & 15 & 167 & 1,0 & 159 & 0,9 & 0,5 & 0,4 \\
\hline Imbituva & 24.496 & 181 & 170 & 2.794 & 17,3 & 2.596 & 14,8 & 13,1 & 8,7 \\
\hline Ipiranga & 13.308 & 23 & 29 & 267 & 1,7 & 149 & 0,9 & 0,4 & 0,9 \\
\hline Irati & 52.352 & 224 & 226 & 2.666 & 16,6 & 2.881 & 16,4 & 15,3 & 15,7 \\
\hline Ivaí & 11.899 & 27 & 35 & 165 & 1,0 & 236 & 1,4 & 1,7 & 1,0 \\
\hline Mallet & 12.602 & 47 & 54 & 459 & 2,9 & 504 & 2,9 & 5,2 & 6,1 \\
\hline Paula Freitas & 5.060 & 19 & 26 & 81 & 0,5 & 100 & 0,6 & 0,1 & 0,6 \\
\hline Paulo Frontin & 6.565 & 28 & 33 & 118 & 0,7 & 151 & 0,9 & 0,4 & 0,5 \\
\hline Porto Vitória & 4.051 & 32 & 37 & 281 & 1,7 & 258 & 1,5 & 1,0 & 0,7 \\
\hline Prudentópolis & 46.346 & 146 & 145 & 951 & 5,9 & 913 & 5,2 & 3,3 & 1,8 \\
\hline Rebouças & 13.663 & 35 & 45 & 286 & 1,8 & 365 & 2,1 & 1,0 & 1,2 \\
\hline Rio Azul & 13.023 & 38 & 44 & 292 & 1,8 & 470 & 2,7 & 1,5 & 3,9 \\
\hline São João do Triunfo & 12.418 & 22 & 27 & 92 & 0,6 & 81 & 0,5 & 0,2 & 0,1 \\
\hline São Mateus do Sul & 36.569 & 113 & 131 & 733 & 4,6 & 1.108 & 6,3 & 19,6 & 23,8 \\
\hline Teixeira Soares & 8.192 & 21 & 25 & 208 & 1,3 & 259 & 1,5 & 0,6 & 1,1 \\
\hline União da Vitória & 48.522 & 287 & 297 & 3.816 & 23,7 & 4.138 & 23,6 & 22,4 & 22,8 \\
\hline Total da Região & 377.274 & 1.617 & 1.669 & 16.112 & 100,0 & 17.525 & 100,0 & 100,0 & 100,0 \\
\hline
\end{tabular}

FONTE: RAIS-MTE, SEFA. Dados elaborados pela autora.

O três segmentos mais importantes da pauta industrial em termos de participação no VAF industrial da região, em 2003, foram: celulose, papel e papelão $(19,3 \%)$; painéis de madeira $(18,9 \%)$ e extração de xisto $(14,0 \%)$, perfazendo um total de 52,3\%. Quanto à participação no total da mão-de-obra industrial ocupada, os três segmentos mais significativos, em 2003, foram: painéis de madeira (33,0\%), madeira serrada $(18,5 \%)$ e celulose, papel e papelão $(19,7 \%)$, totalizando $61,2 \%$ (ver Tabela 2). 
TABELA 2. TOTAL DE ESTABELECIMENTOS, DE EMPREGADOS E PARTICIPAÇÃO NO VALOR ADICIONADO FISCAL DA INDÚSTRIA DA REGIÃO DE IRATI-UNIÃO DA VITÓRIA, SEGUNDO SEGMENTOS DA INDÚSTRIA - PARANÁ - 1999/2003

continua

\begin{tabular}{|c|c|c|c|c|c|c|c|c|}
\hline \multirow[t]{2}{*}{ SEGMENTO } & \multicolumn{2}{|c|}{$\begin{array}{l}\text { TOTAL DE } \\
\text { ESTABELE- } \\
\text { CIMENTOS }\end{array}$} & \multicolumn{4}{|c|}{ EMPREGADOS } & \multicolumn{2}{|c|}{$\begin{array}{c}\text { PART. NO } \\
\text { VAF DA } \\
\text { INDÚSTRIA } \\
\text { DA REGIÃO } \\
(\%) \\
\end{array}$} \\
\hline & 1999 & 2003 & Abs. & $\%$ & Abs. & $\%$ & 1999 & 2003 \\
\hline abate de suínos, bovinos e outras reses & 11 & 5 & 17 & 0,1 & 47 & 0,3 & 0,1 & 0,1 \\
\hline abate de aves & 1 & 2 & 7 & 0,0 & - & - & - & 0,0 \\
\hline embutidos de carnes & - & 5 & - & - & 3 & 0,0 & - & 0,0 \\
\hline pescados & 1 & - & - & - & - & - & 0,0 & - \\
\hline conservas de frutas e legumes & 4 & 3 & 1 & $\mathrm{o}, \mathrm{O}$ & - & - & 0,0 & 0,0 \\
\hline sucos de frutas e de legumes & 1 & - & - & - & - & - & - & - \\
\hline laticínios & 11 & 12 & 153 & 1,0 & 135 & 0,8 & 0,4 & 1,4 \\
\hline moagem de trigo & 6 & 2 & 53 & 0,3 & 54 & 0,3 & 1,0 & 1,0 \\
\hline derivados de milho & 40 & 42 & 61 & 0,4 & 93 & 0,5 & 0,3 & 0,3 \\
\hline Beneficiamento de grãos e vegetais & 49 & 47 & 384 & 2,4 & 194 & 1,1 & 0,1 & 0,6 \\
\hline café & 5 & 3 & 13 & 0,1 & 4 & 0,0 & 0,2 & 0,0 \\
\hline padaria, confeitaria e pastelaria & 49 & 57 & 117 & 0,7 & 157 & 0,9 & 0,3 & 0,3 \\
\hline biscoitos, doces e massas alimentícias & 6 & 8 & 4 & 0,0 & 13 & 0,1 & 0,0 & 0,0 \\
\hline chocolates e balas & 2 & - & - & - & - & - & 0,0 & - \\
\hline ração animal & 1 & 1 & 1 & 0,0 & 1 & 0,0 & 0,0 & 0,0 \\
\hline mate, dietéticos e alimentos diversos & 96 & 100 & 110 & 0,7 & 194 & 1,1 & 6,1 & 2,3 \\
\hline refrigerantes, refrescos e água mineral & 2 & 4 & 1 & $\mathrm{o}, \mathrm{o}$ & 11 & 0,1 & 0,0 & 0,0 \\
\hline vinho e aguardente & 1 & 5 & 3 & 0,0 & 6 & 0,0 & 0,0 & 0,0 \\
\hline cerveja, chope e malte & 2 & - & 1 & 0,0 & - & - & 0,0 & - \\
\hline fumo & 6 & 8 & 80 & 0,5 & 67 & 0,4 & 0,6 & 1,0 \\
\hline $\begin{array}{l}\text { fiação e tecelagem de seda, rami e outras fibras } \\
\text { naturais }\end{array}$ & 5 & 2 & 8 & 0,1 & - & - & 0,0 & 0,0 \\
\hline tecelagem de fibras artificiais & 1 & 2 & - & - & - & - & 0,0 & 0,0 \\
\hline vestuário & 58 & 48 & 71 & 0,4 & 124 & 0,7 & 0,1 & 0,1 \\
\hline malharia, estamparia e têxteis diversos & 72 & 62 & 152 & 0,9 & 171 & 1,0 & 0,4 & 0,2 \\
\hline uniformes e vestuário de segurança & 1 & 4 & - & - & 4 & 0,0 & 0,0 & 0,0 \\
\hline bonés, brindes e outros artefatos têxteis & 2 & 2 & 1 & 0,0 & - & - & 0,0 & 0,0 \\
\hline couro & 6 & 5 & 24 & 0,2 & 27 & 0,2 & 0,0 & 0,1 \\
\hline malas, bolsas e outros artefatos de couro & 5 & 7 & 3 & 0,0 & 2 & 0,0 & 0,0 & 0,0 \\
\hline calçados de couro e outros materiais & 4 & 4 & 48 & 0,3 & 62 & 0,4 & 0,1 & 0,2 \\
\hline madeira serrada & 361 & 346 & 4.074 & 25,3 & 3.244 & 18,5 & 17,0 & 13,3 \\
\hline painéis de madeira & 141 & 154 & $5 \cdot 312$ & 33,0 & $5 \cdot 777$ & 33,0 & 24,0 & 18,9 \\
\hline esquadrias e artefatos de madeira & 97 & 122 & 1.085 & 6,7 & 1.415 & 8,1 & 2,6 & 2,3 \\
\hline celulose, papel e papelão & 19 & 19 & 1.234 & 7,7 & 1.704 & 9,7 & 14,2 & 19,3 \\
\hline
\end{tabular}

FONTE: RAIS-MTE, SEFA. Dados elaborados pela autora. 
TABELA 2. TOTAL DE ESTABELECIMENTOS, DE EMPREGADOS E PARTICIPAÇÃO NO VALOR ADICIONADO FISCAL DA INDÚSTRIA DA REGIÃO DE IRATI-UNIÃO DA VITÓRIA, SEGUNDO SEGMENTOS DA INDÚSTRIA - PARANÁ - 1999/2003

\begin{tabular}{|c|c|c|c|c|c|c|c|c|}
\hline \multirow[t]{2}{*}{ SEGMENTO } & \multicolumn{2}{|c|}{$\begin{array}{l}\text { TOTAL DE } \\
\text { ESTABELE- } \\
\text { CIMENTOS }\end{array}$} & \multicolumn{4}{|c|}{ EMPREGADOS } & \multicolumn{2}{|c|}{\begin{tabular}{|c|} 
PART. NO \\
VAF DA \\
INDÚSTRIA \\
DA REGIÃO \\
$(\%)$
\end{tabular}} \\
\hline & 1999 & 2003 & Abs. & $\%$ & Abs. & $\%$ & 1999 & 2003 \\
\hline artefatos de papel e papelão & 6 & 4 & 19 & 0,1 & 4 & 0,0 & 2,0 & 0,0 \\
\hline mobiliário & 99 & 111 & 230 & 1,4 & 319 & 1,8 & 0,8 & 1,1 \\
\hline edição, impressão e reprodução & 31 & 43 & 63 & 0,4 & 71 & 0,4 & 0,1 & 0,1 \\
\hline carvão vegetal e outros produtos químicos & 38 & 37 & 422 & 2,6 & 450 & 2,6 & 4,4 & 6,1 \\
\hline fertilizantes e defensivos & 3 & 3 & 4 & 0,0 & 14 & 0,1 & 0,3 & 0,7 \\
\hline produtos farmacêuticos e veterinários & 1 & 1 & - & - & - & - & 0,0 & 0,0 \\
\hline higiene e limpeza & 3 & 4 & 6 & 0,0 & 14 & 0,1 & 0,0 & 0,0 \\
\hline perfumarias e cosméticos & 1 & - & - & - & - & - & 0,0 & - \\
\hline tintas, vernizes, solventes e adesivos & 1 & 3 & - & - & 1 & 0,0 & 0,0 & 0,0 \\
\hline pneus e artefatos de borracha & 12 & 8 & 27 & 0,2 & 17 & 0,1 & 0,0 & 0,0 \\
\hline laminados e artefatos de plásticos & 4 & 14 & 47 & 0,3 & 80 & 0,5 & 0,2 & 0,2 \\
\hline embalagens plásticas & 2 & 4 & 69 & 0,4 & 64 & 0,4 & 0,7 & 0,5 \\
\hline artefatos de cimento & 36 & 38 & 121 & 0,8 & 158 & 0,9 & 0,3 & 0,3 \\
\hline cerâmica, porcelanas e louças & 112 & 102 & 1.042 & 6,5 & 1.058 & 6,0 & 10,4 & 8,6 \\
\hline mármores e pedras ornamentais & 2 & 4 & 2 & 0,0 & 10 & 0,1 & 0,0 & 0,0 \\
\hline extração xisto e gás natural & 1 & 1 & - & - & 247 & 1,4 & 8,3 & 14,0 \\
\hline $\begin{array}{l}\text { extração e beneficiamento de calcário e outros } \\
\text { minerais }\end{array}$ & 6 & 1 & - & - & - & - & 0,6 & 0,0 \\
\hline extração de argila, pedra e areia & 34 & 39 & 172 & 1,1 & 233 & 1,3 & 0,9 & 1,9 \\
\hline siderurgia, metalurgia e usinagem de metal & 14 & 15 & 34 & 0,2 & 60 & 0,3 & 0,1 & 0,0 \\
\hline estruturas metálicas de grande porte & 9 & 9 & 26 & 0,2 & 60 & 0,3 & 0,1 & 0,1 \\
\hline serralherias e esquadrias & 43 & 52 & 123 & 0,8 & 117 & 0,7 & 0,3 & 0,3 \\
\hline ferramentas, ferragens, funilaria e cutelarias & 17 & 21 & 33 & 0,2 & 56 & 0,3 & 0,0 & 0,1 \\
\hline equipamentos para agricultura e construção civil & 6 & 6 & 9 & 0,1 & 10 & 0,1 & 0,0 & 0,0 \\
\hline equipamentos industriais e comerciais & 12 & 16 & 47 & 0,3 & 45 & 0,3 & 0,5 & 0,6 \\
\hline máquinas-ferramenta & 2 & 5 & 52 & 0,3 & 56 & 0,3 & - & 0,0 \\
\hline equipamentos para energia elétrica & - & 2 & - & - & - & - & - & 0,0 \\
\hline materiais eletroeletrônicos & 6 & 3 & 2 & 0,0 & 33 & 0,2 & 0,8 & 0,3 \\
\hline equipamentos médico-hospitalares & 2 & - & 2 & 0,0 & - & - & 0,0 & - \\
\hline autopeças & 6 & 5 & 454 & 2,8 & 725 & 4,1 & 1,6 & 3,5 \\
\hline cabines, carrocerias e reboques & 11 & 14 & 28 & 0,2 & 42 & 0,2 & 0,0 & 0,0 \\
\hline equipamentos de transportes diversos & 7 & 1 & 22 & 0,1 & 4 & 0,0 & - & - \\
\hline produtos diversos & 24 & 21 & 38 & 0,2 & 68 & 0,4 & 0,2 & 0,1 \\
\hline Total da região & 1.617 & 1.669 & 16.112 & 100,0 & 17.525 & 100,0 & 100,0 & 100,0 \\
\hline
\end{tabular}

FONTE: RAIS-MTE, SEFA. Dados elaborados pela autora.

Madeira e Papel

A Região de Irati-União da Vitória está localizada em uma região de clima subtropical úmido com características importantes para o crescimento de espécies exóticas para reflorestamento, particularmente pinus e eucalipto. 
As matas e florestas ocupam 34,3\% das áreas utilizadas pelos estabelecimentos agropecuários na região, superior à exploração com pastagens $(18,3 \%)$ e muito próxima da participação das lavouras $(35,1 \%)$ - (Ipardes $2004)$.

As reservas naturais e de reflorestamento da região apresentou, em 2003, um total de 6,0 milhões de $\mathrm{m}^{3}$ de produção de madeira em tora na Região de Irati-União, posicionando na segunda região maior produtora do Estado, dos quais: 1,9 milhões $\mathrm{m}^{3}$ de pinus para serraria, predominantemente nos municípios de Antônio Olinto e General Carneiro; 1,8 milhões de tora de pinus para laminadora, destacando-se os municípios de General Carneiro, Cruz Machado e Bituruna; 1,1 milhão de $\mathrm{m}^{3}$ de madeira para celulose, predominantemente no município de Antônio Olinto; 525 mil de $\mathrm{m}^{3}$ de madeiras em tora para outras finalidades, notadamente no município de Teixeira Soares); $261 \mathrm{mil} \mathrm{m}^{3}$ de outras madeiras em toras para serraria; $168 \mathrm{mil} \mathrm{m}^{3}$ de pinheiro em tora para serraria; $118 \mathrm{mil}$ $\mathrm{m}^{3}$ tora de eucalipto; $64 \mathrm{mil} \mathrm{m}^{3}$ de imbuía em toras. Além das toras de madeira produziu também 1,5 milhão de $\mathrm{m}^{3}$ de lenha; 77,2 mil toneladas de carvão vegetal do tipo churrasco e 27 toneladas de resinas predominantemente nos municípios de General Carneiro e Cruz Machado. A região também gerou em 2003 a produção de 27 milhões de mudas de pinus (Seab/Deral 2003).

O grupo madeira da região congrega 799 empresas industriais e totaliza 55,0\% do VAF da indústria regional, conformando um Arranjo Produtivo Local $(\mathrm{APL})^{2}$.

O segmento de celulose, papel e papelão, que contava, em 2003, com 19 empresas na região apresentou expressivo aumento na participação no VAF da indústria da região, passando de 14,2\% em 1999 para 19,3\% em 2003 (Tabela 02). É também o segmento com maior expressão em nível estadual (ver Tabela 7 do anexo). Destacam-se as empresas Miguel Forte (pasta mecânica, papel duplex e white top liner), Novacki (papel white top liner e semi-kraft) e São Gabriel (papel), todas localizadas em União da Vitória; Sepac (papel higiênico das marcas Paloma e KS) e Serpasta (celulose e pasta mecânica), em Mallet; Dallegrave (papel semikraft, miolo e caixa papelão), em Irati, e Santa Clara (semi-kraft, capa, miolo), em Ivaí (Simpacel 2001).

Em relação à mão-de-obra ocupada do segmento de celulose, papel e papelão, verificou-se crescimento expressivo nos postos de trabalho ofertados que passou de 1.234 trabalhadores em 1999 para 1.704 em 2003. Analisando o perfil da mão-de-obra do segmento observou-se que a maioria $(51,7 \%)$ ainda possuía o nível básico em 2003, porém houve crescimento na participação do estrato que detinha nível funda-

2 Ver mais sobre o tema em Martini (2004) e Rodrigues (2003). 
mental (passando de 23,1\% do total dos trabalhadores do segmento em 1999 para 28,1\% em 2003) e nível médio (de 10,2\% em 1999 para $18,2 \%$ em 2003). No que tange aos salários dos trabalhadores do segmento, cresce a participação daqueles que auferiam até $2 \mathrm{SMs}^{3}(19,1 \%$ do total do contingente em 1999 e 39,1\% em 2003); pode-se inferir que novos postos de trabalho forma criados no segmento para os trabalhadores que recebiam rendimentos nessa faixa. Na composição da faixa etária dos trabalhadores a maioria estava na faixa de 25 a 39 anos de idade (52,7\% em 1999 e 49,8\% em 2003), tendo-se elevado um pouco a participação daqueles com mais de 39 anos, de $28,2 \%$ do total dos trabalhadores do segmento em 1999 para 31,9\% em 2003. A maioria do pessoal ocupado $(90,0 \%)$ é de homens, mas a participação da mão-de-obra feminina vem crescendo no segmento, passando de 5,0\% em 1999 para 10,0\% em 2003. As principais ocupações profissionais ${ }^{4}$ do segmento são: alimentadores de linhas de produção ${ }^{5}$, operadores de máquinas de desdobramento da madeira, operadores de máquinas de fabricar papel e papelão e preparadores de pasta para fabricação de papel (ver Tabelas 3 a 6 do anexo).

Também se impõe na região o segmento de painéis de madeira tanto pelo número de empresas quanto pela participação na renda da indústria. Em 2003, o segmento era formado por 154 empresas e apresentou significativa perda na sua participação no total do VAF industrial da região, declinando de 24,0\% em 1999 para 18,9\% em 2003, mesmo assim, manteve-se como a segunda maior participação no VAF regional. Destacam-se as empresas: Compensados LFPP, Madereira Belo Horizonte e Laminados Diwal, em Imbituva; Emílio Gomes \& Filhos, em Irati; Formacomp e Thomasi, ambas de União da Vitória; Pizzatto, em General Carneiro e Rossoni, em Bituruna.

No que se refere à mão-de-obra do segmento de painéis de madeira, observou-se crescimento no contigente empregado passando de 5.312 em 1999 para 5.777 em 2003. Quanto ao grau de instrução dos empregados lotados no segmento, verificou-se que a grande maioria $(65,6 \%)$ detinha o nível básico, mas a participação daqueles que possuíam o nível fundamental registrou melhoria, pois passou de 21,4\% em 1999 para 25,8\% em 2003. Já no que se refere aos salários, a maioria recebia até 2 SMs (salários mínimos); a participação do estrato que recebia até este patamar passou de 57,9\% do total do contingente em 1999 para $68,4 \%$ em 2003, demonstrando que a rotatividade ou os novos postos

O salário mínimo (SM) em dezembro de 1999 era de R \$ 136,00 e em dezembro de 2003 de R\$240,oo.

4 Qualificação do emprego: é definida pela empresa a partir das exigências do posto de trabalho, sendo que no Brasil está consolidada na CBO (Classificação Brasileira das Ocupações). A qualificação é de natureza qualitativa e as classificações profissionais são sua expressão quantitativa.

5 As empresas em geral enquadram nesta categoria aqueles trabalhadores que pertenciam à classificação no CBO de 1994 como Trabalhadores braçais não-classificados sob outras epígrafes. 
de trabalho se deram com redução dos salários dos trabalhadores. A participação nas faixas etárias dos trabalhadores do segmento tem se mantido nos mesmos patamares, com a maioria (em torno de 47\%), compondo a faixa entre 25 e 39 anos. O gênero predominante (em torno de $86,0 \%$ ) era do sexo masculino. As ocupações que mais absorviam empregados no segmento, em 2003, foram: alimentadores de linhas de produção, trabalhadores de tratamento e preparação da madeira, operadores de máquinas de desdobramento da madeira e operadores de máquinas de aglomeração e prensagem de chapas.

Em 2003, o parque produtivo do segmento de madeira serrada era composto de 346 estabelecimentos. Nesse parque, sublinham-se as empresas Affonso Ditzel, em Prudentópolis; Rio Claro, em Rio Azul; Madebil e Geyer, em Bituruna e Baum, em Imbituva. Registrou-se redução na participação do segmento no VAF industrial da região passando de $17,0 \%$ em 1999 para 13,3\% em 2003.

No que se refere à mão-de-obra do segmento madeira serrada, observou-se redução no contigente empregado passando de 4.074 em 1999 para 3.244 em 2003. Isto pode ser explicado pelo fato que várias empresas passaram a produzir produtos com maior valor agregado tais como painéis de madeira, isto pode ser constatado na redução do número de estabelecimentos, que de 361 em 1999 declinou para 346 estabelecimentos. Quanto ao grau de instrução dos empregados lotados no segmento verificou-se que embora a maioria $(73,8 \%$ em 1999 e $67,1 \%$ em 2003) detivesse apenas a instrução básica, houve um pequeno avanço com a elevação da participação daqueles que detinham fundamental completo (passando de 21,9\% em 1999 para 26,7\% em 2003). No que se refere aos salários, a maioria aferia até 2 SMs (salários mínimos), crescendo o contigente que recebia até este patamar (passando de $61,3 \%$ do total do contingente em 1999 para 77,3\% em 2003). Como o segmento reduziu o número de empregados, constata-se que a rotatividade da mão-de-obra foi acompanhada pela redução salarial. A participação nas faixas etárias dos trabalhadores do segmento tem se mantido nos mesmos níveis para os diversos estratos, a maior parcela (em torno de 44,0\%) situando-se na faixa entre 25 e 39 anos. A maioria (93,6\% em 1999 e 90,2\% em 2003) dos trabalhadores eram do sexo masculino. As ocupações que mais absorviam empregados no segmento, em 2003, foram: de alimentadores de linhas de produção, peradores de máquinas de desdobramento da madeira e trabalhadores de tratamento e preparação da madeira.

Com 122 estabelecimentos na região, o segmento de esquadrias e artefatos de madeira atua, principalmente, na produção de portas e janelas, tornou-se especialidade nessas atividades; evidenciando as empresas Pormade, em União da Vitória; Madecaixa, em São Mateus do Sul; Randa, 
em Bituruna; Helios, em Imbituva, e Kampmann, em Porto Vitória. O segmento apresentou pequena retração na participação do VAF da indústria da região, passando de 2,6\% em 1999 para 2,2\% em 2003.

No que tange à mão-de-obra do segmento de esquadrias e artefatos de madeira observou-se aumento no contigente empregado, que passou de 1.085 em 1999 para 1.415 em 2003. Quanto ao grau de instrução dos empregados lotados no segmento, verificou-se que a maior parte $(56,5 \%$ em 1999 e 44,9\% em 2003) detinha o nível básico; entretanto, registrou-se melhoria na participação daqueles que detinham o nível médio, que passou de 9,4\% em 1999 para 19,4\% em 2003. Já no que se refere aos salários, cresceu a participação daqueles que auferiam até 2 SMS (passando de 41,9\% do total do contingente de empregados do segmento em 1999 para 64,0\% em 2003). A participação nas faixas etárias dos trabalhadores dos segmento tem se mantido inalterada, com a maior parcela (em torno de $48,0 \%$ do total de trabalhadores do segmento) situando na faixa entre 25 e 39 anos de idade. Majoritariamente os trabalhadores do segmento (90\% em 2003) eram homens. As ocupações que mais absorviam empregados no segmento, em 2003, foram: operadores de máquinas de desdobramento da madeira, operadores de usinagem convencional de madeira, alimentadores de linhas de produção e operadores de máquina de usinar madeira (produção em série).

Outra atividade conexa ao setor madeireiro é a produção de móveis, que não aproveitou amplamente as externalidades presentes na região, como a produção de aglomerados e compensados, bem como a mão-deobra qualificada.

\section{Minerais Não-Metálicos e Químicos}

O módulo industrial da Superintendência de Exploração do Xisto (SIX) da Petrobrás em São Mateus do Sul extraiu e processou, em 2003, cerca de 13 mil toneladas de gás de xisto, $22 \mathrm{mil} \mathrm{m}^{3}$ de gás liqüefeito de petróleo (GLP), $40 \mathrm{mil} \mathrm{m}^{3}$ de nafta e $4 \mathrm{mil} \mathrm{m}^{3}$ de outros não-energéticos (Mineropar 2005). A participação do segmento de extração e processamento de xisto evoluiu fortemente no total do VAF industrial da Região, tendo passado de 8,3\% em 1999 para 14,0\% em 2003.

No que tange à novos investimentos no segmento, a direção da unidade da Petrobrás pretende aportar cerca de $\mathrm{R} \$ 15$ milhões na construção de uma usina de biodiesel em São Mateus do Sul e a capacidade de processamento da fábrica poderá alcançar 40 mil toneladas ano. A empresa aguarda um levantamento sobre o potencial produtivo de oleaginosas na região (Orgis 2005). 
Identificando a composição do emprego no segmento de extração e processamento de xisto e gás da região, verificou-se que as informações fornecidas na RAIS referem-se somente a 2003, com um total de 247 empregados. Cabe destacar o elevado nível de qualificação de mão-deobra do segmento. Observa-se um bom nível de instrução do contigente de trabalhadores, sendo que o estrato que possui o nível médio corresponde a $60,7 \%$ do total de trabalhadores do segmento e $37,7 \%$ com nível completo (segmento regional com maior índice de instrução superior). No que se refere aos salários, $14,2 \%$ dos trabalhadores do segmento auferem entre 7 e 15 SMs e $82,2 \%$ têm rendimentos superiores a 15 SMs. O segmento comporta 39,0\% de empregados com mais de 39 anos de idade e 54,6\% na faixa de 25 a 39 anos. Em 2003, a maioria dos trabalhadores do segmento $(96,5 \%)$ era do sexo masculino. As principais ocupações no segmento, em 2003, eram compostas por: operadores de equipamentos de filtragem e separação, técnicos de planejamento e controle de produção, engenheiros mecânicos e engenheiros químicos.

A atividade extrativa de argila e fornecimento de gás natural advindo da unidade da Petrobrás de São Mateus contribuiu para posicionar a região como segundo maior pólo de cerâmica do Estado, suplantado apenas pela região Metropolitana de Sul-Curitiba. O pólo reúne 102 empresas, predominantemente empresas de cerâmica vermelha e de pequeno porte dedicadas à produção de tijolos e telhas, notadamente localizadas nos municípios de Guamiranga, Imbituva e Prudentópolis. Interessante observar o predomínio da localização das unidades produtoras nas fases lindeiras das rodovias BR-373, BR-476 e BR-277. Destaca-se a unidade de cerâmica branca da Incepa, empresa de grande porte que responde por $38,1 \%$ da produção de pisos e revestimentos do Paraná ( 8 milhões $\mathrm{m}^{2} /$ ano), com 254 empregados e localizada em São Mateus do Sul. A participação do segmento no VAF industrial da região apresentou queda, passando de 10,3\% em 1999 para 8,6\% em 2003.

Quanto à mão-de-obra ocupada no segmento de cerâmica, porcelanas e louças manteve-se praticamente inalterada (1.042 trabalhadores em 1999 e 1.058 em 2003). Registram-se melhorias no nível de instrução dos trabalhadores do segmento; a participação daqueles que detinham o fundamental completo passou de 20,1\% em 1999 para 23,6\% em 2003 e daqueles que possuíam grau médio passou de 10,5\% em 1999 para $19,2 \%$ em 2003. No que tange aos salários, o percentual nas diversas faixas salariais manteve-se em índices próximos no período analisado (1999-2003), com a maioria (57,8\% em 2003) auferindo até 2 SMs. No que se refere à idade dos trabalhadores, o segmento abriga um percentual razoável de empregados mais velhos, com $18,8 \%$ do total do contingente em 1999 e $21,2 \%$ em 2003 , entretanto a maioria $(54,2 \%)$ está na faixa de 25 a 39 anos de idade. Os homens são a maioria na composição de 
gênero dos trabalhadores do segmento. As principais ocupações do segmento são trabalhadores da fabricação de cerâmica estrutural, ceramistas (preparação e fabricação), alimentadores de linhas de produção e trabalhadores na operação de máquinas de terraplenagem e fundações.

A expansão da atividade de extração de argila, pedra e areia (a participação no VAF da região evoluiu de 0,9\% em 1999 para 1,9\% em 2003) deve-se à presença de grandes reservas de argila vermelha na região, predominantemente nos municípios de Imbituva, Prudentópolis e Paula Freitas, oriundas das unidades geológicas denominadas formação Irati e Serra Alta. Os demais bens minerais explorados foram: a areia, em União da Vitória e Porto Vitória; argila em São Mateus do Sul, Guamiranga e Imbituva, e rocha para brita em Irati. Vale sublinhar que os municípios de União da Vitória e Porto Vitória constituem importantes portos de areia do Estado, registrando-se produção de $368.422 \mathrm{~m}^{3}$ do mineral em 2001 (Mineropar 2003).

Atividade que também tem um importante significado para a economia regional é o carvão vegetal e químicos diversos, que apresentou evolução positiva na participação do VAF industrial da Região, passando de 4,4\% em 1999 para 6,1\% em 2003. O segmento é composto de 37 unidades em operação, e nele se evidencia a empresa Fosforeira Brasileira (fósforo de segurança das marcas Paraná e Líder), em Irati - pertencente ao grupo espanhol Inácio Ferro, líder mundial do segmento, com o aproveitamento da produção de madeira (para os palitos) e do enxofre (da SIX/Petrobras) da Região. Na produção de carvão vegetal ${ }^{6}$, distinguemse as empresas Carvorite, de Irati, e a Superbrasa, de Cruz Machado. Cabe destacar a produção de briquetes de carvão ${ }^{7}$ da Central de Processamento Energético de União da Vitória (Cepevil), instalada em 2003, no município de União da Vitória, resultado de investimentos na ordem de US\$ 3,5 milhões, com capacidade para produzir 35 mil toneladas/ano de carvão compactado (briquete da marca Carvonet). Na ponta produtiva da matéria-prima estima-se o envolvimento de mais de mil famílias de produtores de carvão na região (Gazeta Mercantil 2003).

6 O carvão vegetal é produzido a partir da lenha (em geral de bracatinga) pelo processo de carbonização ou pirólise. A carbonização de lenha é praticada de forma tradicional em fornos de alvenaria com ciclos de aquecimento e resfriamento que duram até vários dias.

7 A briquetagem de carvão vegetal é um processo que permite aproveitar os carvões na forma de fios, ou então, carbonizar resíduos na forma de partículas e depois compactá-los. O briquete é um pequeno bloco de forma pré-definida, resultante da aplicação de pressão em uma mistura de finos de carvão com um aglutinante, dentro de moldes matrizes, através de orifícios entre cilindros rotativos ou outros artifícios semelhante. Os aglutinantes podem ser de natureza diversa, sendo que os mais utilizados comercialmente são de amido de milho. No Brasil busca-se utilizar o amido de mandioca, pela abundância desse produto. Os briquetes também são utilizados para queima em siderúrgicas, caldeiras, fornos e lareiras (Revista da Madeira 2005). 


\section{Alimentos e Bebidas}

Atuam três agroindústrias cooperativadas na região: a Cooperativa de Laticínios de Curitiba (Clac), laticínios (União da Vitória); Cooperativa Central Agropecuária Sudoeste (Sudcoop), laticínios (União da Vitória) e Cooperativa Agropecuária Irineópolis (Coopergril), beneficiamento de grãos e cereais (Paulo Frontin). Apenas a Coopergril tem sede na região. Também atuam na região a Cooperativa Agrícola Mista de Prudentópolis (Camp) e a Cooperativa de Irati (Cooperati), entretanto ainda não industrializam os produtos agropecuários de seus cooperativados. Interessante observar que a Cooperativa Mista Bom Jesus mantém vários entrepostos de recebimento na região.

A Região caracteriza-se por contribuir significativamente na produção brasileira de erva-mate - 37,6\% do total produzido no Brasil (IBGE 2005). É detentora da maior produção estadual, com total de 188,6 mil toneladas, em 2003, correspondendo a $64 \%$ do total da cultura no Estado, e é também responsável pela produção de 4,4 milhões de mudas de ervamate, em 2003 (Seab/Deral 2003). Dentre as 100 empresas do segmento mate, dietéticos e alimentos diversos, 80 fazem parte do parque ervateiro, evidenciando-se entre elas as empresas Leão Junior, em Fernandes Pinheiro; Baldo e Ervateira São Mateus, ambas de São Mateus do Sul, e Santa Fé, em Paulo Frontin. A participação do segmento no VAF da indústria da região declinou drasticamente, passando de 6,0\% em 1999 para 2,3\% em 2003. Perspectiva para o setor, ainda não explorada é a produção de blends extratos, essências e concentrados de ervamate.

A elevada produção de leite na região (58,4 milhões de litros em 2003) beneficia o segmento de laticínios, que congrega 12 estabelecimentos, capitaneados pelas empresas Schreiber (queijos tipo Cheiddar), em Rio Azul e pelas unidades de União da Vitória das Cooperativas Clac e Sudcoop e o Laticínios Anila, em Irati. Com relação à participação do segmento no total do VAF da indústria da Região, esta mostrou evolução positiva, passando de 0,4\% em 1999 para 1,4\% em 2003.

Aproveitando as condições favoráveis ao plantio (extensas áreas de várzeas), a região detém a maior área plantada de $\operatorname{arroz}^{8}$ do Estado, com 11 mil hectares (15,3\% da área plantada no Estado do grão e $0,4 \%$ do total plantado no Brasil), gerando 20,6 mil toneladas do cereal (10\% do total produzido no Estado e 0,2\% da produção brasileira), em 2003. Estão contabilizados 47 estabelecimentos, que compõem o segmento de beneficiamento de grãos e outros vegetais, destacando-se as empre-

8 A agroindústria de engenho de arroz, que produz arroz parboilizado, arroz polido, longo e fino (agulhinha), arroz parbolizado, arroz integral, arroz para colônia oriental. 
sas: Lima \& Cia, em União da Vitória, e a unidade da Cooperativa Coopergril em Paulo Frontin.

O segmento de derivados de milho é composto de 42 unidades industriais, destacando-se a Pianaro Ângelo, em Rebouças, e Alessi \& Filhos, em Irati.

Há dois moinhos de trigo instalados na região um em Irati, a S/A Moageira e outro em União da Vitória, o Moinho União da Vitória.

$\mathrm{Na}$ divisão de bebidas cabe observar que a região é a terceira maior produtora de uva vinífera do Estado, em 2003, totalizou 1,7 mil toneladas em área plantada de 338 hectares, que reforçam as atividades industriais na região, que conta com 5 vinícolas, destacando-se o município de Bituruna (em 2003, com 140 hectares com parreirais, gerando 552 toneladas da fruta). A atividade é beneficiada pelas características do solo (semelhante ao da Serra Gaúcha), que é propício à cultura. Há investimentos do programa do Governo do Estado ("Paraná 12 meses") para alavacangem da cultura (parreirais e mudas) e para movimentar o setor ocorrem, anualmente, desde a década de 1940, a Festa da Uva em Bituruna.

Outra atividade que vem despontando como alternativa econômica é a aqüicultura. Embora não se constitua em atividade tradicional na região (com produção de apenas 797 toneladas de peixes, predominantemente de carpas, pescado de captura, tilápia e bagre, onde a região aparece em $7^{\circ}$. lugar no ranking estadual nessa atividade) é beneficiada pelos recursos fluviais de água, notadamente nos municípios ribeirinhos do Rio Iguaçu (Seab/Deral 2003). O potencial de produção de pescado na região também é reforçado pela existência de uma estação de piscicultura em União da Vitória, que é responsável pela produção anual de um milhão de alevinos, que são comercializados na Feira do Peixe em União da Vitória (Jornal O Comércio 2005). Levantamento realizado em 1997 contabilizava cerca de 470 lâminas d'água em União da Vitória e aproximadamente 200 lâminas, em Irati. Muitas são as restrições para o desenvolvimento do setor, entre elas as normas ambientais, que regulamentam a construção de tanques-rede. Com este potencial desenvolvido a Região poderia capitanear a produção de pescado no Estado.

No setor agropecuário há várias atividades em crescimento na Região, destacando-se, em 2003, no ranking estadual os seguintes produtos:

1. maior produtora de mel $^{9}$ do Estado, com um total de 1,6 mil toneladas, destacando-se o municípios de São João do Triunfo (280 toneladas) e Prudentópolis (275 toneladas);

9 Segundo dados apresentados no XII Simpósio Paranaense de Apicultura, em 1997, o Estado do Paraná possuía cerca de 30.000 apicultores, com média de 15 colméias por propriedade e produção média de $15 \mathrm{~kg}$ por colméia/ano. 
2. segunda na produção de batatas (6 mil hectares plantados que geram 122,6 mil toneladas);

3. segunda na produção de cebola (23 mil toneladas, 30\% do total produzido no Estado);

4. segunda na produção de pinhão (834 toneladas, $38 \%$ da produção estadual);

5. segunda na criação de caprinos de corte (plantel de 22 mil cabeças, 19\% total do rebanho estadual);

6. segunda na criação de coelhos (4 mil cabeças, representando $13 \%$ do rebanho do Estado) e a produção de lã (6o toneladas);

7. segundo maior viveiro de mudas de pessegueiro do Estado, com produção de 18 mil unidades;

8. terceira posição na criação de perus para corte (notadamente nos municípios de Imbituva e Teixeira Soares);

9. terceira na produção de cevada com 8 mil hectares $(15,32 \%$ do total da área plantada dessa cultura no Estado).

Fumo

Em 2003, a região detinha a maior área plantada de fumo do Estado, com 24,9 mil hectares (46\% do total da área plantada da cultura em nível estadual e $6,4 \%$ do total da área plantada em nível nacional) gerando no mesmo ano em 47,9 mil toneladas, em áreas localizadas, notadamente nos municípios de Rio Azul, Prudentópolis e Ipiranga (Seab/Deral 2003; IBGE 2005). O segmento industrial de fumo conta com oito empresas processadoras, destacando-se Meridional Tabacos, em Rio Azul e Flor do Norte, em União da Vitória. A participação do segmento no VAF da indústria da região evoluiu de 0,6\% em 1999 para 1,0\% em 2003. A situação atual da produção do fumo é bastante peculiar. O segmento acompanha o desenrolar da campanha da Organização Mundial da Saúde no aguardo de que no mínimo 40 países ratifiquem o Primeiro Tratado Internacional de Saúde Pública, denominado Convenção Quadro, com o objetivo do controle do tabagismo. O fato acarretou forte resistência dos agricultores em reduzir esta atividade. Neste sentido, ações de apoio a uma gradual reconversão da cultura arrefeceriam o impacto econômicos e cultural para a região. 


\section{Confecções e Outros Segmentos}

Em 2003, o segmento de malharia, estamparia e têxteis diversos da região contava com 62 empresas, das quais 52 estavam concentradas no município de Imbituva, conformando um Arranjo Produtivo Local $(\mathrm{APL})^{10}$ de malhas. Em 2004, o segmento produziu cerca de $100 \mathrm{mil}$ peças por mês. (Gazeta do Povo 2004)

Entre os segmentos com participação significativa no VAF da indústria da região está também o de autopeças. Em 1999, o segmento respondia por 1,6\% do total do VAF regional e em 2003 passou a representar 3,5\%. São cinco empresas operando no segmento: SY Wiring, Iracome e Yasaki, todas localizadas em Irati e que manufaturam chicotes elétricos, e as empresas produtoras de baterias Fundiplac, em Paula Freitas, e Acumuladores Irati, em Irati.

Ao identificar a composição dos trabalhadores ocupados no segmento de autopeças, verificou-se que apresentou evolução positiva no número de postos de trabalho, passando de 454 em 1999, para 725 em 2003. Houve uma melhoria expressiva no grau de instrução dos trabalhadores ocupados nesse segmento sendo que a participação daqueles que possuem o nível médio passou de 37,2\% em 1999 para 60,1\% em 2003. Entretanto o nível salarial não acompanha essa evolução, a maioria $(67,3 \%$ em 1999 e $63,7 \%$ em 2003) auferia rendimentos na faixa entre 2 a 4 SMs. Há um grande contigente de trabalhadores jovens (até 24 anos de idade) lotados no segmento (43,7\% em 1999 e 52,5\% em 2003). A maioria (57,5\% do contigente) era composta por mulheres. As principais ocupações do segmento são: alimentadores de linhas de produção, técnicos de controle da produção, escriturários em geral, agentes, assistentes e operadores de equipamentos de acabamento de chapas e metais.

\section{Fatores sistêmicos regional}

\section{Ativos tecnológicos e institucionais}

São quatro instituições de ensino superior atuando na região: Fundação Faculdade Municipal de União da Vitória (Face/Uniuv), que tem como mantenedora o município de União da Vitória; Faculdade Estadual de Filosofia Ciências Letras União da Vitória (Fafi); unidades de ensino da Universidade Estadual do Centro-Oeste (Unicentro) em Irati e Prudentopólis, mantidas pelo governo do Estado do Paraná; e uma instituição particular, Unidade de Ensino Superior Vale do Iguaçu (Uniguaçu), em União da Vitória.

10 Ver mais sobre o tema na publicação em Hoffman \& Lins (2002). 
No que se refere à cursos com ênfase à indústria, a Face/Uniuv mantém curso de engenharia da madeira, em União da Vitória, e a Unicentro fornece o curso de engenharia florestal, em Irati.

Cabe destacar a Empresa Junior da Face/Uniuv ligada ao curso de economia que presta serviços de consultoria por meio da empresa META. Não há registro da existência de grupo de pesquisa no cadastro do Conselho Nacional de Desenvolvimento Científico e Tecnológico (CNPq) nas instituições locais.

No que tange ao cursos técnicos e profissionalizantes, o Colégio Técnico de União da Vitória Ensino Médio e Profissional (Coltec) oferece o curso Técnico profissional em informática. O Senai oferece os seguintes cursos: eletricista de manutenção industrial (Carga horária de 300 horas), mecânico de manutenção industrial (300), mecânico de manutenção industrial (300), mancais de rolamentos/deslizamento (40), metrologia industrial básica (51), lubrificação industrial (40), operador de empilhadeira (20) e operador de caldeira (40).

Cabe registrar a existência de escritórios regionais da Empresa de Assistência Técnica e Extensão Rural (Emater) nos municípios de Irati e União da Vitória.

No que se refere aos ativos organizacionais - self-help, que são instituições públicas e privadas que dão suporte aos agentes econômicos, atuam na região o Serviço Brasileiro de Apoio as Micro e Pequenas Empresas (Sebrae) e Instituto Euvaldo Lodi (IEL), instituição do Sistema Federação das Indústrias Paranaense (FIEP) que prestam consultoria especializada aos Arranjos Produtivos Locais, destacando-se na atuação de acompanhamento do Arranjo Produtivo Local (APL) da Madeira de União da Vitória.

São três associações de municípios atuando na região: a Associação dos Municípios do Centro Sul do Paraná (Amcespar), que congregam os municípios Fernandes Pinheiro, Guamiranga, Imbituva, Irati, Mallet, Prudentópolis, Rebouças, Rio Azul e Teixeira Soares; a Associação dos Municípios do Sul do Paraná (Amsulpar) que reúne os municípios Antônio Olinto, Bituruna, Cruz Machado, General Carneiro, Paula Freitas, Paulo Frontin, Porto Vitória, São João do Triunfo, São Mateus do Sul e União da Vitória; e Associação dos Municípios da Região dos Campos Gerais (AMCG) com dois municípios Ipiranga e Ivaí.

\section{Infra-Estrutura}

As condições existentes na infra-estrutura de transportes (sistema viário, ferroviário e portos), bem como sua disponibilidade, qualidade, confiabilidade e distâncias são elementos vitais no processo de desen- 
volvimento de uma região. No caso da região de Irati-União da Vitória, a principal via de transporte da região é a rodovia BR 476 - denominada "Rodovia do Xisto", a estrada Curitiba - São Mateus do Sul que foi construída mediante convênio entre o DER e a Petrobrás na década de 1960. A rodovia também favorece o escoamento de toda a produção agrícola e de produtos da madeira da região sudeste do Paraná, por isso, adiante de São Mateus do Sul a estrada toma o nome de "Rodovia da Madeira". Outra opção de acesso à região consiste na PR-151, procedente de Sengés/SP, que após o entroncamento com a BR-277 em Palmeira, atinge São João do Triunfo e posteriormente São Mateus do Sul e na seqüência, incorpora-se ao traçado da BR-476 em direção a União da Vitória. Vale particularizar a BR-153 (Transbrasiliana), que atravessa o centro do país e, na região, passa pelos municípios de Imbituva, Irati, Rebouças, Rio Azul, Mallet, Paulo Frontin, Paula Freitas, União da Vitória e General Carneiro e, na continuidade, extrapola os limites estaduais, alcançando Santa Catarina e abrigando efetivamente a circulação entre o oeste catarinense e o porto de Paranaguá. Há também a PR-170, que promove a ligação da região com o município de Guarapuava. Em direção ao Estado de Santa Catarina a BR-28o liga a região ao Porto de São Francisco e a SC-302 que dá acesso ao centro-sul catarinense (Ipardes 2004).

A região conta, em seu território, com um trecho da ferrovia que liga Guarapuava ao porto de Paranaguá) passa, dentro da região, pelos municípios de Irati, onde há uma estação de passagem, Fernandes Pinheiro e Teixeira Soares, além de um pequeno trecho da linha que une Ponta Grossa a Apucarana (antiga Central do Paraná) que passa pelo município de Ipiranga. A região possui somente um aeroporto público, em União da Vitória (Ipardes 2004).

\section{Instituições Representativas}

Representando o setor patronal industrial estão constituídas na região seis entidades representativas, sendo elas: Sindicato das Indústrias de Cerâmicas e Olarias da Região Centro Sul do Paraná (Sincosul), com sede em Guamiranga; Sindicato da Indústria da Madeira de Imbituva; Sindicato das Indústrias de Serrarias, Carpintarias, Tanoarias, Madeiras Compensadas e Laminadas de União da Vitória (Sindpatronal); Sindicato da Indústria de Serrarias, Carpintarias e Tanoarias e da Marcenaria de Irati; Associação dos Produtores de Uva e Vinho de Bituruna (Apruviti) e a Associação dos produtores de malhas (Imbitumalhas).

$\mathrm{Na}$ representação dos trabalhadores estão presentes na região quatro sindicatos: Sindicato dos Trabalhadores nas Indústrias da Construção e Mobiliária de Irati; Sindicato Trabalhadores Indústria da Construção e 
Mobiliária União da Vitória (sede em União da Vitória e sub-sedes em Bituruna e General Carneiro); Sindicato Trabalhadores Indústria da Fiação e Tecelagem de Imbituva e a sub-sede do Sindicato dos Petroleiros do Paraná, em São Mateus do Sul.

\section{Considerações finais}

No Quadro 2, caracterizam-se os elementos intervenientes e condicionantes no processo do desenvolvimento regional, com as oportunidades a serem aproveitadas, gargalos a serem rompidos, e as restrições a serem removidas.

\section{QUADRO 2. ELEMENTOS INTERVENIENTES DO DESENVOLVIMENTO RE- GIONAL}

\begin{tabular}{|c|c|c|}
\hline VARIÁVEIS-CHAVE & ELEMENTOS & CARACTERÍSTICAS \\
\hline Variáveis-estrutura & $\begin{array}{l}\text { Atividades produtivas } \\
\text { Estruturantes }\end{array}$ & $\begin{array}{l}\text { Madereira (celulose e papel, painéis e esquadrias de madeira) } \\
\text { e minerais não-metálicos (xisto e cerâmica) }\end{array}$ \\
\hline Variáveis-estrutura & $\begin{array}{l}\text { Atividades com } \\
\text { possibilidade de expansão }\end{array}$ & $\begin{array}{l}\text { Madereira (PMVA e briquetes de carvão), malharia, uva e } \\
\text { vinho, aqüicultura, beneficiamento de arroz, abate de } \\
\text { caprinos e de coelhos e produção de blends da erva-mate, } \\
\text { exploração dos resíduos do xisto. }\end{array}$ \\
\hline Variáveis-estrutura & Formação de mão-de-obra & $\begin{array}{l}\text { Baixo aproveitamento pelas empresas dos alunos de } \\
\text { engenharia da madeira da FACE/UNIV } \\
\text { Existem apenas } 47 \text { engenheiros trabalhando nas indústrias } \\
\text { da região } \\
\text { Faltam cursos de formação técnica para a área madeireira } \\
\text { Faltamcursos de formação técnica para área de alimentos }\end{array}$ \\
\hline Variáveis-complemento & Silvicultura & $\begin{array}{l}\text { A região é a segunda maior produtora de produtos florestais } \\
\text { (toras de madeira) do Estado }\end{array}$ \\
\hline Variáveis-prospecção & Capital social & $\begin{array}{l}\text { Grau baixo de interação e organização dos atores locais } \\
\text { Excesso de associações de municípios (fragmentação da } \\
\text { organização inter-municipal) }\end{array}$ \\
\hline Variáveis-prospecção & Ativos Tecnológicos & $\begin{array}{l}\text { Três instituições de ensino superior (duas públicas e uma } \\
\text { privada) }\end{array}$ \\
\hline Variáveis-prospecção & $\begin{array}{l}\text { Ativos Institucionais } \\
\text { Entidades líderes }\end{array}$ & $\begin{array}{l}\text { Seis entidades de classe patronal } \\
\text { Quatro entidades representativas dos trabalhadores } \\
\text { industriais }\end{array}$ \\
\hline Variáveis-prospecção & Infra-estutura & $\begin{array}{l}\text { Acesso rodoviário (BR-376; BR-153; BR-280; PR 151 e PR- } \\
\text { 170) } \\
\text { Acesso ferroviário pela face norte da região } \\
\text { Transporte por barcas (entre municípios ribeirinhos ao Rio } \\
\text { Iguaçu) } \\
\text { Aeroporto (municipal em União da Vitória para aeronaves de } \\
\text { pequeno porte, não há vôos comerciais ) }\end{array}$ \\
\hline Variáveis-prospecção & $\begin{array}{l}\text { Dilemas e } \\
\text { constrangimentos }\end{array}$ & $\begin{array}{l}\text { Fumo (Convenção Quadro) } \\
\text { Restrições ao plantio de pinus próximo às reservas de matas } \\
\text { nativas }\end{array}$ \\
\hline
\end{tabular}

FONTE: Elaboração da autora.

Utilizando-se da metodologia apresentada no tópico 2 desse artigo, fezse uma leitura sintética da estrutura regional que pode ser assim descrita: não houve modificações importantes na estrutura e no modus operadi da Região de Irati-União da Vitória, no período analisado (1999/2003), que manteve a mesma matriz industrial produtiva e, com tendência de continuidade. Sendo assim, novas rotas de diversificação produtiva 
dependerão de novos requerimentos de qualificação empresarial e laboral, bem como de alterações na estrutura produtiva agrícola da Região.

Entre os segmentos-região que freqüentam os indicadores de dinamismo alto estão aqueles inseridos nas divisões de madeira e minerais nãometálicos.

No setor de madeireiro, com empresas forjadas desde os anos 1960, destacam-se os segmentos de celulose e papel, painéis de madeira, serradas de madeira e esquadrias de madeira e outros artefatos de madeira. No segmento de serrados de madeira, os dados indicam uma reorientação para produto de mais intensidade tecnológica como os Produtos de Maior Valor Agregado (PMVA) como os derivados do pinus, entre eles os clear blocks ${ }^{11}$.

O setor minerais não-metálicos tem se constituído em importante gerador de empregos e apresenta-se na região com toda a cadeia produtiva (extração e beneficiamento de xisto e gás), argila e areia (tijolos e telhas de cerâmica vermelha, revestimentos (cerâmica branca). Existem ainda alguns fatores que favorecem o florescimento de indústrias cerâmicas, tais como a abundância de argilas e a produção de lenha, fonte energética utilizada para cerâmica vermelha, e o gás explorado pela Petrobrás em São Mateus do Sul, que é o combustível preferencial da indústria de cerâmica branca. Outro fator importante de fomento a novos investimentos na região, além do cerâmico, é aquele advindo da reutilização dos rejeitos do processamento do xisto, cujas características físico-químicas regulares e homogêneas podem servir de matériaprima para outros segmentos industriais.

Desdobramentos mais prováveis para região, principalmente tendo em conta os investimentos que vêm sendo realizados, apontam para a manutenção da matriz produtiva atual.

Se no passado os conflitos fundiários e de fronteira territorial eram os grandes problemas da Região, a análise desenvolvida evidenciou dois dilemas a enfrentar na região. Um deles refere-se à atividade florestal, cada vez mais constrangida pelas leis ambientais ${ }^{12}$ e o outro refere-se à cultura do fumo.

11 Destinam-se à confecção de molduras, esquadrias, revestimentos, partes e peças aparentes de móveis, ou são vendidos diretamente aos consumidores, para uso próprio (do-it-yourself) ou bricolagem. Os clears, emendados nos topos por finger joint, formam peças mais longas, conhecidas como blanks (Revista da Madeira 2005).

12 Aplicação do decreto estadual 3320/o4, que aprova os critérios, normas, procedimentos e conceitos aplicáveis ao Sisleg (Sistema de manutenção, recuperação e proteção da reserva florestal legal e áreas de preservação permanente), que torna ainda mais rígidas as regras do Código Florestal 
No que diz respeito ao fumo, as restrições são em função de tratados que o Brasil assina para os produtos nocivos à saúde. Movimentações e audiências públicas sobre o tema na Região, põem em evidência as dificuldades de se equacionar esse dilema. Pode-se afirmar que há uma tendência de continuidade dessa atividade, pois a forte cultura fumageira entre os agricultores da região e os altos retornos financeiros trabalham em favor dessa tendência. A proposta da reconversão produtiva e a mensuração do impacto dessa reconversão não foram totalmente delineadas, esforços deverão ser direcionados para a exploração de novas ruralidades.

Quanto ao dilema florestal, as perspectivas não são ainda muito promissoras, a atividade florestal está cada vez mais constrangida pelas leis ambientais. $\mathrm{O}$ apagão florestal não está totalmente descartado. $\mathrm{O}$ fato de que se cortam 28 mil hectares de área reflorestadas por ano no estado, embora o plantio some algo entre $34 \mathrm{mil} \mathrm{e} 40$ mil hectares por ano, e de que 1991 a região produzia 27 milhões de metros cúbicos de produtos florestais, caindo vertiginosamente para 5 milhões de metros cúbicos em 2003, impõem-se como alerta e forte motivação para ampliação da silvicultura de pinus e eucaliptos na região. Grandes desafios são colocados diante das características peculiares/singulares de regiões tradicionais, como a região de Irati-União da Vitória, que não diversificaram sua base produtiva mantendo-se naqueles setores com fortes imbricações extrativistas, cabendo romper com esta cultura mediante ao fortalecimento de sua estrutura reflorestadora.

A análise do item mão-de-obra revela alguns elementos que merecem destaque. A estrutura ocupacional da região é marcada pelo elevado peso das ocupações de menor qualificação, com baixos salários e diminuta participação de engenheiros dentre os quadros funcionais das empresas. Por outro lado verifica-se melhoria significativa da escolarização da mão-de-obra industrial da região, particularmente daqueles que detinham o nível básico (de 1 a 7 anos de estudos) que passam a deter o fundamental (entre 8 e 10 anos de estudos), o que vem ao encontro do aumento da demanda pelas indústrias locais por trabalhadores mais instruídos. Observou-se que nos segmentos do xisto e da cerâmica estavam os trabalhadores mais instruídos e também o maior número de engenheiros nos seus quadros funcionais.

no Paraná, ampliando as áreas de preservação das matas nativas para protegê-las de espécies invasoras e a criação de cinco novas áreas de preservação no Paraná. Espécies invasoras são aquelas espécies não nativas que, uma vez introduzidas a partir de outros ambientes, se adaptam e passam a reproduzir-se rapidamente através da polinização a ponto de ocupar com sucesso o espaço das espécies nativas, tornando-se, muitas vezes, dominantes no novo ambiente impedindo o crescimento do bioma natural. As espécies Pinus taeda e Pinus elliotti apresentam-se como favoráveis à invasão em áreas de vegetação de campos, mais do que em florestas. Isto se deve ao seu elevado percentual de germinação, resistência ao fogo e longevidade. 
No que se refere ao ensino profissionalizante, a Região vem de certa maneira suprindo essa demanda com os cursos do Serviço Nacional de Aprendizagem Industrial (Senai) e do Coltec, além do curso de engenharia da madeira (com ênfase na indústria). Chama atenção a falta de cursos técnicos voltados para a agroindústria e silvicultura. A Região ainda padece de deficiência na parceria universidade-empresa, e os estudantes do curso de Engenharia da Madeira não estão sendo devidamente absorvidos pelas indústrias locais.

A Região ressente-se da falta de movimentos e pactos entre agentes locais, públicos e privados, para estimular a criação de uma institucionalidade territorial capaz de favorecer o fomento econômico e a capacidade inovadora local, realçar a capacidade local de iniciativa e dar um destaque especial aos atores sociais (stakeholders) locais e regionais. Além disso, esforços devem ser empregados para criar efeitos complementares e sinérgicos entre a infra-estrutura física e social e atividades produtivas, o chamado capital social local, que seja capaz de identificar e articular interesses, recursos financeiros, humanos, conhecimentos, experiências, competências e saberes local.

A construção desse capital social regional poderia ser efetivada por meio da criação de uma organização "guarda-chuva" que agrupe mais eficazmente as forças econômicas da região (pivô de integração de proposta regionais e setoriais), através da institucionalização no formato de um Fórum ou Conselho de Desenvolvimento Regional. A tal organização caberia articular os diversos agentes, de modo a promover a mobilização dos recursos endógenos (agregando as experiências locais calcadas em planos de desenvolvimento a partir de seus próprios alicerces), assim como, atrair recursos exógenos.

Essa institucionalização poderia ser articulada em seminários regionais em que o apoio de instituições-ponte, como as universidades locais, é fundamental para a identificação/hierarquização de problemas, visando a induzir, construir, incentivar, priorizar, divulgar projetos de desenvolvimento a partir da "visão de futuro" que a Região tem de si. No conjunto destes elementos, destaca-se sobremaneira a relevância das políticas públicas para a Região, de maneira a evitar que estas atuem de forma fragmentada e percam a capacidade de promover ações estratégicas que objetivem a exploração de oportunidades potencialmente geradoras de resultados e com impactos dinamizadores sobre a base produtiva, multiplicando e pulverizando seus efeitos encadeadores par frente e para trás. 


\section{Referências}

BANDEIRA, Pedro S. (1995). “A economia da região Sul.” In AFFONSO, R. B. A. \& SILVA, P. L. B. (org.). Federalismo no Brasil. São Paulo: Unesp.

CALDERON, Cynthia (2003). "Paraná vai produzir carvão compactado para exportação." Gazeta Mercantil, São Paulo, 31 de março, Caderno Região Sul, p. 3 .

DIÁRIO DO POVO 2003. "Lançada com estilo a Festa do Vinho de Bituruna." Diário do Povo. URL: www.diariodeguarapuava.com.br. Acesso em: 14 de julho de 2003.

DIAS, M. F. \& OLIVEIRA, M. A. (2005). "Economia mineral paranaense: distribuição da produção, empregos e valor adicionado." In Encontro de Economia Paranaense - IV Ecopar: Unioeste,Toledo/PR, 3 e 4 de novembro de 2005. CD ROM.

DEQUECH, Candice (2004). "Paraná é o maior exportador de madeira.” Folha de Londrina, 17 de março, Caderno Economia, p. 1.

GAZETA DO POVO (2004). "Malharias de Imbituva trabalham 24 horas por dia." Gazeta do Povo, Caderno Economia, 27 de maio, p. 26.

HOFFMANN, R. \& LINS, H. N. (2002). "Iniciativas e impasses em uma pequena aglomeração confeccionista: as malharias de Imbituva (PR) na ótica do debate sobre aglomerações industriais”. In Encontro de Economia Paranaense - I Ecopar, Maringá.

IBGE (2005). "Sistema IBGE de Recuperação Automática (Sidra)". Instituto Brasileiro de Georafia e Estatística. URL: http://www.sidra.ibge.gov.br/ bda. Acesso em: 10 de junho de 2005.

IPARDES (2003). Arranjos produtivos locais e o novo padrão de especialização regional da indústria paranaense na década de noventa. Curitiba.

(2004). Mesorregião sudeste. Leituras Regionais.

JORNAL O Comércio, Investimentos na piscicultura são discutidos. União da Vitória: O Comércio, 4 de agosto de 2005, p. 12.

MARTINI, Suely T. (Coord.). (2004). Diagnóstico da cadeia produtiva da madeira dos municípios de União da Vitória/PR e Porto União/SC. União da Vitória: FACE/META-Consultoria Empresa Junior.

MINEROPAR (2003). Informativo anual sobre a produção de substâncias minerais no Paraná. Curitiba.

OLIVEIRA, M A. (2003). "Indústria paranaense na década de 1990: reestruturação e concentração.” In Encontro de Economia Paranaense - II Ecopar: Maringá, pp. 499-516, ISSN 1679-5814. CD ROM.

(2005). "Matriz Regional-econômica para o Estado do Paraná: nova regionalização e segmentos industriais representativos.” In Simpósio Alternativas de Regionalização com vistas ao Planejamento do Desenvolvimento do Território. I Jornada de Economia Regional Comparada, 4-5 nov. 2005, Porto Alegre. CD ROM.

ORGIS, Guido (2005). "Petrobras pretende abrir usina de biodisel em São Mateus do Sul." Gazeta do Povo, 15 de abril:17. 
PARANÁ (2002a). Secretaria de Estado da Agricultura e do Abastecimento. Departamento de Economia Rural. Divisão de Estatística Básica. Produção agropecuária municipal do Estado do Paraná: safra 2001/2002. Curitiba, 1 disquete $3^{1 / 2}$.

(2002b).Secretaria de Estado da Fazenda. Coordenação de Assuntos Econômicos. Valor adicionado. 1 disquete $3^{1 / 2}$.

RAIS-MTE (2005). Ministério do Trabalho. Relação anual de informações sociais: RAIS 1999 e 2003. Brasília, CD-ROM.

REVISTA DA MADEIRA (2005) "Produtos da madeira." URL: www.remade.com.br. Acesso em: 10 de setembro de 2005.

RODRIGUES, R. M. (2003). Interações em aglomerados industriais: um estudo na indústria da madeira da região de União da Vitória. Florianópolis: UFSC. $202 p$.

SEAB/DERAL (2003). "Produção agropecuária municipal do Estado do Paraná: Safra 1999/2000 e 2002/2003." Secretaria de Estado da Agricultura e do Abastecimento, Departamento de Economia Rural/Divisão de Estatística Básica, Curitiba. CD ROM.

SEFA (2003). "Valor adicional Fiscal para os anos 1999 e 2003." Secretaria do Estado da Fazenda, Coordenação de Assuntos Econômicos, Curitiba. CD ROM.

SEMA (2005). "Programa de Reflorestamento do Paraná, Secretaria de Governo do Meio Ambiente do Estado do Paraná." URL: www.sema.pr.gov.br. Acesso em: 10 de abril de 2005.

SIMPACEL (2001). Relação dos fabricantes de celulose, papel, papelão e artefatos do Estado do Paraná. Curitiba.

Recebido em: 25 nov. 2005 Aceite em: 10 maio 2006 
TABELA 3. DISTRIBUIÇÃO PERCENTUAL, SEGUNDO O NÍVEL DE INSTRUÇÃO DOS TRABALHADORES OCUPADOS NOS SEGMENTOS INDUSTRIAIS COM MAIS DE 100 EMPREGADOS DA REGIÃO DE IRATI-UNIÃO DA VITÓRIA- 1999/2003

\begin{tabular}{|c|c|c|c|c|c|c|c|c|}
\hline \multirow{3}{*}{ SEGMENTOS } & \multicolumn{8}{|c|}{ DISTRIBUIÇÃO POR NÍVEL DE INSTRUÇÃO (\%) } \\
\hline & \multicolumn{2}{|c|}{ BÁSICA } & \multicolumn{2}{|c|}{$\begin{array}{c}\text { FUNDAMEN- } \\
\text { TAL }\end{array}$} & \multicolumn{2}{|c|}{ MÉDIA } & \multicolumn{2}{|c|}{ SUPERIOR } \\
\hline & 1999 & 2003 & 1999 & 2003 & 1999 & 2003 & 1999 & 2003 \\
\hline painéis de madeira & 73,2 & 65,6 & 21,4 & 25,8 & 4,1 & 7,1 & 1,2 & 1,5 \\
\hline madeira serrada & 73,8 & 67,1 & 21,9 & 26,7 & 3,7 & 5,5 & 0,5 & 0,7 \\
\hline celulose, papel e papelão & 65,3 & 51,7 & 23,1 & 28,1 & 10,2 & 18,2 & 1,4 & 2,0 \\
\hline esquadrias e artefatos de madeira & 56,5 & 44,9 & 31,7 & 32,9 & 9,4 & 19,4 & 2,3 & 2,8 \\
\hline cerâmica, porcelanas e louças & 68,8 & 56,3 & 20,1 & 23,6 & 10,5 & 19,2 & 0,7 & 0,9 \\
\hline autopeças & 19,6 & 5,1 & 34,2 & 30,1 & 37,2 & 60,1 & 9,0 & 4,7 \\
\hline carvão vegetal e outros produtos químicos & 65,0 & 66,6 & 14,3 & 14,9 & 16,8 & 14,3 & 3,9 & 4,2 \\
\hline mobiliário & 53,8 & 44,5 & 32,3 & 32,9 & 12,2 & 20,7 & 1,7 & 1,9 \\
\hline extração xisto e gás natural & - & 0,4 & - & 1,2 & - & 60,7 & - & 37,7 \\
\hline extração de argila, pedra e areia & 53,7 & 43,3 & 31,3 & 35,6 & 12,2 & 18,0 & 2,8 & 3,0 \\
\hline mate, dietéticos e alimentos diversos & 60,1 & 60,8 & 28,7 & 21,6 & 10,1 & 15,5 & 1,1 & 2,1 \\
\hline beneficiamento de grãos e vegetais & 80,7 & 51,5 & 12,9 & 27,8 & 4,3 & 17,5 & 2,1 & 3,1 \\
\hline malharia, estamparia e têxteis diversos & 44,4 & 45,0 & 47,2 & 44,4 & 5,2 & 8,2 & 3,2 & 2,3 \\
\hline artefatos de cimento & 53,6 & 46,8 & 38,5 & 46,2 & 7,8 & 5,7 & - & 1,3 \\
\hline padaria, confeitaria e pastelaria & 39,6 & 29,3 & 41,6 & 51,0 & 18,8 & 18,5 & - & 1,3 \\
\hline laticínios & 51,8 & 36,3 & 33,3 & 28,1 & 9,2 & 27,4 & 5,6 & 8,1 \\
\hline vestuário & 40,5 & 50,8 & 37,4 & 35,5 & 20,2 & 12,1 & 1,8 & 1,6 \\
\hline serralherias e esquadrias & 51,3 & 46,2 & 41,2 & 37,6 & 7,6 & 14,5 & - & 1,7 \\
\hline
\end{tabular}

FONTE: RAIS-MTE. NOTA: Elaboração da autora.

TABELA 4. DISTRIBUIÇÃO PERCENTUAL, SEGUNDO AS FAIXAS SALARIAIS DOS TRABALHADORES OCUPADOS NOS SEGMENTOS INDUSTRIAIS COM MAIS DE 100 EMPREGADOS DA REGIÃO DE IRATI-UNIÃO DA VITÓRIA - 1999/2002

\begin{tabular}{|c|c|c|c|c|c|c|c|c|c|c|}
\hline \multirow{3}{*}{ SEGMENTOS } & \multicolumn{10}{|c|}{ DISTRIBUIÇÃO POR FAIXAS DE SALÁRIOS MÍNIMOS (\%) } \\
\hline & \multicolumn{2}{|c|}{0,5 A 2,0 } & \multicolumn{2}{|c|}{2,01 A 4,0} & \multicolumn{2}{|c|}{ 4,01 A 7,o } & \multicolumn{2}{|c|}{7,01 A 15} & \multicolumn{2}{|c|}{ MAIOR 15} \\
\hline & 1999 & 2002 & 1999 & 2002 & 1999 & 2002 & 1999 & 2002 & 1999 & 2002 \\
\hline painéis de madeira & 57,9 & 68,4 & 34,6 & 26,5 & 5,2 & 3,9 & 1,9 & 0,9 & 0,4 & 0,4 \\
\hline madeira serrada & 61,3 & 77,3 & 34,0 & 19,3 & 3,3 & 2,7 & 1,1 & 0,6 & 0,4 & 0,1 \\
\hline celulose, papel e papelão & 19,1 & 39,1 & 53,7 & 45,3 & 19,1 & 10,5 & 7,3 & 3,5 & 0,8 & 1,7 \\
\hline esquadrias e artefatos de madeira & 41,9 & 64,7 & 55,5 & 32,9 & 2,5 & 2,2 & 0,1 & 0,2 & - & - \\
\hline cerâmica, porcelanas e louças & 51,4 & 57,8 & 31,4 & 31,5 & 10,3 & 8,1 & 6,0 & 2,2 & 0,9 & 0,4 \\
\hline autopeças & 5,6 & 26,1 & 67,3 & 63,7 & 9,8 & 4,0 & 10,1 & 4,3 & 7,2 & 2,0 \\
\hline carvão vegetal e outros produtos & 36,3 & 60,4 & 47,2 & 25,6 & 9,5 & 8,9 & 4,9 & 3,8 & 2,1 & 1,3 \\
\hline mobiliário & 52,0 & 68,4 & 37,9 & 26,8 & 8,9 & 4,8 & 1,2 & - & - & - \\
\hline extração xisto e gás natural & - & 0,4 & - & - & - & 3,2 & - & 14,2 & - & 82,2 \\
\hline extração de argila, pedra e areia & 25,1 & 35,2 & 56,0 & 46,7 & 16,6 & 16,7 & 2,3 & 1,3 & - & - \\
\hline mate, dietéticos e alimentos diversos & 60,9 & 43,0 & 28,6 & 46,1 & 7,5 & 7,8 & 3,0 & 2,6 & - & 0,5 \\
\hline beneficiamento de grãos e vegetais & 37,8 & 66,1 & 52,3 & 27,6 & 5,5 & 4,7 & 3,5 & 1,0 & 0,9 & 0,5 \\
\hline malharia, estamparia e têxteis diversos & 90,7 & 92,4 & 8,6 & 7,0 & 0,6 & 0,6 & - & - & - & - \\
\hline artefatos de cimento & 31,1 & 64,9 & 63,9 & 31,8 & 3,4 & 3,2 & 1,7 & - & - & - \\
\hline padaria, confeitaria e pastelaria & 83,5 & 90,8 & 14,7 & 7,9 & 1,8 & 1,3 & - & - & - & - \\
\hline laticínios & 42,2 & 28,9 & 42,2 & 44,4 & 8,8 & 17,0 & - & 3,7 & 6,9 & 5,9 \\
\hline serralherias e esquadrias & 82,4 & 86,2 & 16,5 & 9,5 & 1,2 & 3,4 & - & 0,9 & - & - \\
\hline
\end{tabular}

FONTE: RAIS-MTE. NOTA: Elaboração da autora. 
TABELA 5. DISTRIBUIÇÃO PERCENTUAL SEGUNDO A FAIXA ETÁRIA DOS TRABALHADORES OCUPADOS NOS SEGMENTOS INDUSTRIAIS COM MAIS DE 100 EMPREGADOS DA REGIÃO DE IRATI-UNIÃO DA VITÓRIA- 1999/2003

\begin{tabular}{|c|c|c|c|c|c|c|}
\hline \multirow{3}{*}{ SEGMENTOS } & \multicolumn{6}{|c|}{ DISTRIBUIÇÃO POR FAIXA ETÁRIA (\%) } \\
\hline & \multicolumn{2}{|c|}{ ATÉ 24 ANOS } & \multicolumn{2}{|c|}{$\begin{array}{c}\text { ENTRE } 25 \mathrm{E} \\
\text { 39 ANOS }\end{array}$} & \multicolumn{2}{|c|}{$\begin{array}{c}40 \text { ANOS OU } \\
\text { MAIS }\end{array}$} \\
\hline & 1999 & 2002 & 1999 & 2002 & 1999 & 2002 \\
\hline painéis de madeira & 31,5 & 27,6 & 46,3 & 47,9 & 22,2 & 24,5 \\
\hline madeira serrada & 30,7 & 29,8 & 44,5 & 44,0 & 24,9 & 26,2 \\
\hline celulose, papel e papelão & 19,1 & 18,3 & 52,7 & 49,8 & 28,2 & 31,9 \\
\hline esquadrias e artefatos de madeira & 32,1 & 28,2 & 48,2 & 48,4 & 19,6 & 23,4 \\
\hline cerâmica, porcelanas e louças & 27,5 & 24,7 & 53,7 & 54,2 & 18,8 & 21,2 \\
\hline autopeças & 43,7 & 52,5 & 51,9 & 43,6 & 4,4 & 3,9 \\
\hline carvão vegetal e outros produtos químicos & 20,8 & 18,2 & 52,7 & 52,5 & 26,5 & 29,3 \\
\hline mobiliário & 33,7 & 32,7 & 45,7 & 43,9 & 20,6 & 23,4 \\
\hline extração de argila, pedra e areia & 15,8 & 14,2 & 51,8 & 48,6 & 32,4 & 37,2 \\
\hline malharia, estamparia e têxteis diversos & 28,3 & 20,0 & 53,1 & 52,0 & 18,6 & 28,0 \\
\hline extração xisto e gás natural & - & 6,4 & - & 54,6 & - & 39,0 \\
\hline artefatos de cimento & 21,0 & 13,4 & 61,0 & 69,4 & 18,0 & 17,2 \\
\hline beneficiamento de grãos e vegetais & 29,2 & 18,8 & 48,9 & 56,3 & 22,0 & 25,0 \\
\hline mate, dietéticos e alimentos diversos & 25,0 & 20,7 & 44,2 & 43,1 & 30,8 & 36,2 \\
\hline vestuário & 24,7 & 23,8 & 47,3 & 48,6 & 28,0 & 27,6 \\
\hline serralherias e esquadrias & 38,7 & 33,0 & 45,3 & 50,0 & 16,0 & 17,0 \\
\hline
\end{tabular}

FONTE: RAIS-MTE. NOTA: Elaboração da autora.

TABELA 6. DISTRIBUIÇÃO PERCENTUAL SEGUNDO GÊNERO DOS TRABALHADORES OCUPADOS NOS SEGMENTOS INDUSTRIAIS COM MAIS DE 100 EMPREGADOS DA REGIÃO DE IRATIUNIÃO DA VITÓRIA- 1999/2003

\begin{tabular}{l|c|c|c|c}
\hline \multirow{2}{*}{\multicolumn{1}{c|}{ SEGMENTOS }} & \multicolumn{2}{c|}{ FEMININO } & \multicolumn{2}{c}{ MASCULINO } \\
\cline { 2 - 5 } & 1999 & 2002 & 1999 & 2002 \\
\hline painéis de madeira & 12,5 & 14,3 & 87,5 & 85,7 \\
madeira serrada & 6,4 & 9,8 & 93,6 & 90,2 \\
celulose, papel e papelão & 5,0 & 10,0 & 95,0 & 90,0 \\
esquadrias e artefatos de madeira & 10,1 & 9,8 & 89,9 & 90,2 \\
cerâmica, porcelanas e louças & 3,2 & 1,6 & 96,8 & 98,4 \\
autopeças & 47,0 & 57,5 & 53,0 & 42,5 \\
carvão vegetal e outros produtos químicos & 37,1 & 31,4 & 62,9 & 68,6 \\
mobiliário & 10,3 & 5,2 & 89,7 & 94,8 \\
extração de argila, pedra e areia & 8,1 & - & 91,9 & 100,0 \\
malharia, estamparia e têxteis diversos & 85,7 & 84,1 & 14,3 & 15,9 \\
extração xisto e gás natural & 7,4 & 3,5 & 92,6 & 96,5 \\
artefatos de cimento & 4,5 & - & 95,5 & 100,0 \\
beneficiamento de grãos e vegetais & 7,1 & 7,0 & 92,9 & 93,0 \\
mate, dietéticos e alimentos diversos & 13,2 & 7,8 & 86,8 & 92,2 \\
vestuário & 90,5 & 86,7 & 9,5 & 13,3 \\
serralherias e esquadrias & 0,9 & 1,0 & 99,1 & 99,0 \\
\hline
\end{tabular}

FONTE: RAIS-MTE. NOTA: Elaboração da autora. 
TABELA 7. TOTAL DE EMPREGADOS E PARTICIPAÇÃO NO VALOR ADICIONADO FISCAL DA INDÚSTRIA DO ESTADO DO PARANÁ, SEGUNDO SEGMENTOS INDUSTRIAIS DA REGIÃO DE IRATIUNIÃO DA VITÓRIA - 1999/2003

Continua

\begin{tabular}{|c|c|c|c|c|c|c|}
\hline \multirow[t]{3}{*}{ SEGMENTO } & \multicolumn{4}{|c|}{ EMPREGADOS } & \multicolumn{2}{|c|}{$\begin{array}{c}\text { PART. NO VAF } \\
\text { DO } \\
\text { ESTADO } \\
\end{array}$} \\
\hline & \multicolumn{2}{|c|}{1999} & \multicolumn{2}{|c|}{2003} & & \\
\hline & Abs. & $\%$ & Abs. & $\%$ & 1999 & 2003 \\
\hline celulose, papel e papelão & 1.234 & 0,371 & 1.704 & 0,394 & 0,358 & 0,361 \\
\hline painéis de madeira & $5 \cdot 312$ & 1,595 & 5.777 & 1,337 & 0,531 & 0,354 \\
\hline extração xisto e gás natural & - & - & 247 & 0,057 & 0,183 & 0,263 \\
\hline madeira serrada & 4.074 & 1,223 & 3.244 & 0,751 & 0,377 & 0,250 \\
\hline cerâmica, porcelanas e louças & 1.042 & 0,313 & 1.058 & 0,245 & 0,229 & 0,160 \\
\hline carvão vegetal e outros produtos químicos & 422 & 0,127 & 450 & 0,104 & 0,096 & 0,114 \\
\hline autopeças & 445 & 0,134 & 725 & 0,168 & 0,035 & 0,065 \\
\hline mate, dietéticos e alimentos diversos & 110 & 0,033 & 194 & 0,045 & 0,134 & 0,043 \\
\hline esquadrias e artefatos de madeira & 1.085 & 0,326 & 1.415 & 0,328 & 0,058 & 0,042 \\
\hline extração de argila, pedra e areia & 172 & 0,052 & 233 & 0,054 & 0,019 & 0,035 \\
\hline laticínios & 153 & 0,046 & 135 & 0,031 & 0,010 & 0,026 \\
\hline mobiliário & 230 & 0,069 & 319 & 0,074 & 0,017 & 0,021 \\
\hline fumo & 80 & 0,024 & 67 & 0,016 & 0,014 & 0,019 \\
\hline moagem de trigo & 53 & 0,016 & 54 & 0,012 & 0,023 & 0,019 \\
\hline fertilizantes e defensivos & 4 & 0,001 & 14 & 0,003 & 0,008 & 0,012 \\
\hline equipamentos industriais e comerciais & 47 & 0,014 & 45 & 0,010 & 0,011 & 0,012 \\
\hline beneficiamento de grãos e vegetais & 384 & 0,115 & 194 & 0,045 & 0,002 & 0,010 \\
\hline embalagens plásticas & 69 & 0,021 & 64 & 0,015 & 0,015 & 0,009 \\
\hline artefatos de cimento & 121 & 0,036 & 158 & 0,037 & 0,006 & 0,006 \\
\hline materiais eletroeletrônicos & 2 & 0,001 & 33 & 0,008 & 0,017 & 0,006 \\
\hline serralherias e esquadrias & 123 & 0,037 & 117 & 0,027 & 0,007 & 0,005 \\
\hline derivados de milho & 61 & 0,018 & 93 & 0,022 & 0,006 & 0,005 \\
\hline padaria, confeitaria e pastelaria & 117 & 0,035 & 157 & 0,036 & 0,006 & 0,005 \\
\hline laminados e artefatos de plásticos & 47 & 0,014 & 80 & 0,019 & 0,003 & 0,004 \\
\hline malharia, estamparia e têxteis diversos & 152 & 0,046 & 171 & 0,040 & 0,008 & 0,004 \\
\hline calçados de couro e outros materiais & 48 & 0,014 & 62 & 0,014 & 0,001 & 0,004 \\
\hline vestuário & 71 & 0,021 & 124 & 0,029 & 0,002 & 0,003 \\
\hline abate de suínos, bovinos e outras reses & 17 & 0,005 & 47 & 0,011 & 0,001 & 0,002 \\
\hline estruturas metálicas de grande porte & 26 & 0,008 & 60 & 0,014 & 0,002 & 0,002 \\
\hline produtos diversos & 38 & 0,011 & 68 & 0,016 & 0,003 & 0,001 \\
\hline couro & 24 & 0,007 & 27 & 0,006 & 0,001 & 0,001 \\
\hline ferramentas, ferragens, funilaria e cutelarias & 33 & 0,010 & 56 & 0,013 & 0,001 & 0,001 \\
\hline edição, impressão e reprodução & 63 & 0,019 & 71 & 0,016 & 0,002 & 0,001 \\
\hline siderurgia, metalurgia e usinagem de metal & 43 & 0,013 & 60 & 0,014 & 0,001 & 0,001 \\
\hline
\end{tabular}


TABELA 7. TOTAL DE EMPREGADOS E PARTICIPAÇÃO NO VALOR ADICIONADO FISCAL DA INDÚSTRIA DO ESTADO DO PARANÁ, SEGUNDO SEGMENTOS INDUSTRIAIS DA REGIÃO DE IRATIUNIÃO DA VITÓRIA - 1999/2003

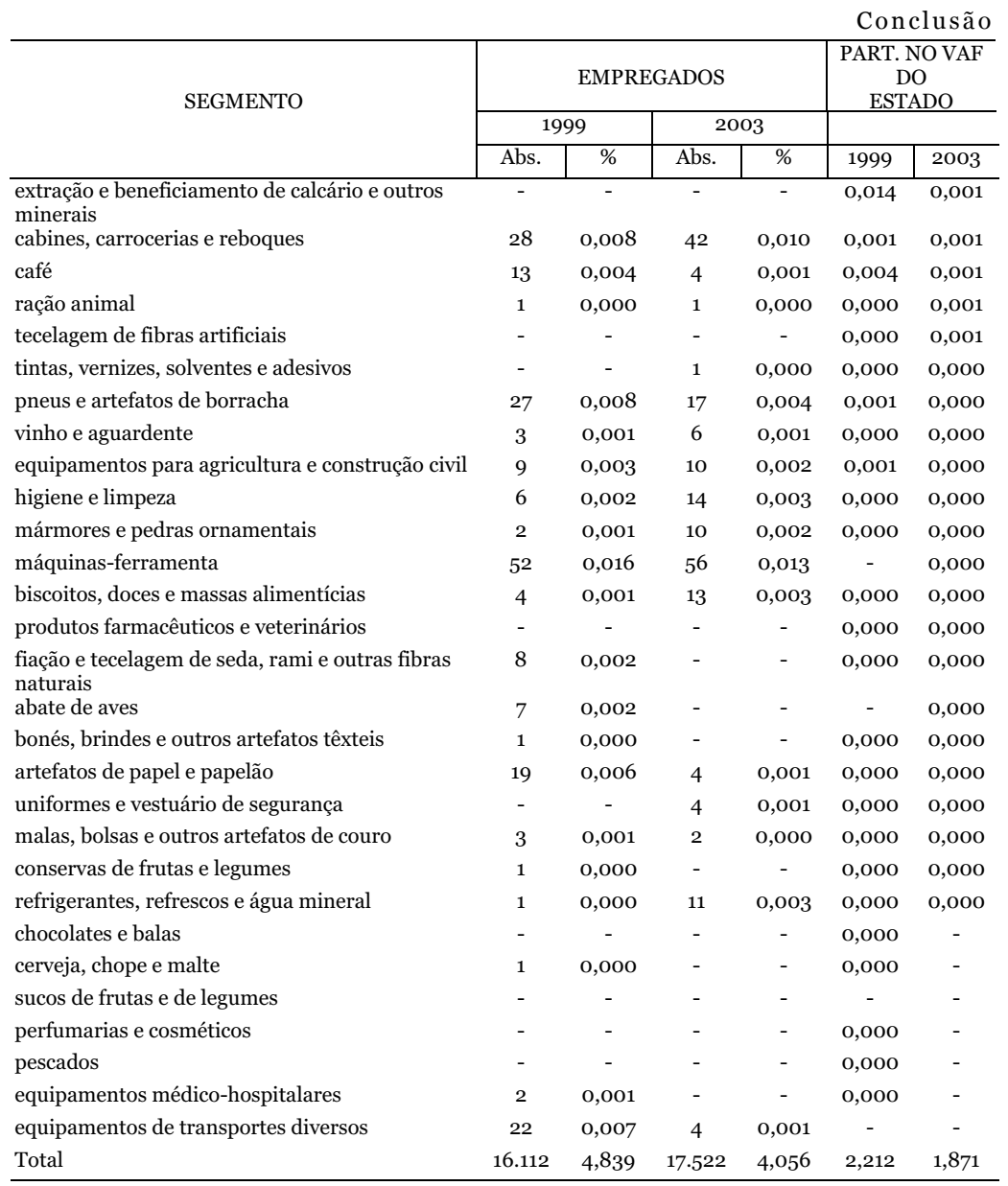

FONTE: RAIS-MTE. NOTA: Adaptação da autora. 